\title{
Mapping domains and mutations on the skeletal muscle ryanodine receptor channel
}

Jean H. Hwang ${ }^{1}$, Francesco Zorzato ${ }^{2,3}$, Nigel F. Clarke ${ }^{1,4} *$, Susan Treves ${ }^{2,3} *$

1. Institute for Neuroscience and Muscle Research, Children's Hospital at Westmead, Sydney, 2145, Australia

2. Departments of Anesthesia and Biomedizin, Basel University Hospital, 4031 Basel, Switzerland

3. Department of Experimental and Diagnostic Medicine General Pathology section, University of Ferrara, Ferrara, 44100 Italy

4. Discipline of Paediatrics and Child Health, University of Sydney, Sydney, NSW 2006 Australia

* These authors have contributed equally to the work.

Corresponding author: Treves, S. (susan.treves@unibas.ch)

Key Words: ryanodine receptor type 1, excitation-contraction coupling, calcium signalling, skeletal muscle, protein interactions, domains, disease pathogenesis

\section{ABSTRACT}

The skeletal muscle ryanodine receptor isoform 1 (RyR1) is a calcium release channel involved in excitation-contraction coupling, the process whereby an action potential is translated to a cytoplasmic $\mathrm{Ca}^{2+}$ signal that activates muscle contraction. Dominant and recessive mutations in RYR1 cause a range of muscle disorders, including malignant hyperthermia and several forms of congenital myopathies. Many aspects of disease pathogenesis in ryanodinopathies remain uncertain, particularly for those myopathies due to recessive mutations. A thorough understanding of the ryanodine receptor macromolecular complex and its interactions with proteins and small molecular modulators is an essential starting point from which to investigate disease mechanisms.

\section{Ryanodine Receptor Function in Normal and Diseased Muscle}


Rapid changes in the intracellular calcium concentration $\left(\left[\mathrm{Ca}^{2+}\right]_{i}\right)$ are important signalling events in most eukaryotic cells, necessitating tight regulation of cytoplasmic $\mathrm{Ca}^{2+}$ levels. Global increases in $\left[\mathrm{Ca}^{2+}\right]_{i}$ are triggered by the release of $\mathrm{Ca}^{2+}$ from the endoplasmic reticulum (ER)/sarcoplasmic reticulum (SR) intracellular stores and/or by calcium influx from the extracellular environment via opening of specific plasma membrane channels. The primary organelle involved in storing rapidly releasable $\mathrm{Ca}^{2+}$ is the SR in striated muscles and the ER in most other mammalian cell types. Two families of channels are responsible for mediating rapid calcium release from these intracellular stores: ryanodine receptors (RyRs) which are predominantly expressed in excitable cells and inositol 1,4,5-triphosphate receptors (IP $\left.{ }_{3} \mathrm{Rs}\right)$ which are expressed in most cells.

The skeletal muscle SR calcium release channel protein was first identified at the biochemical level in the 1980s and was named for its ability to bind the plant alkaloid ryanodine. Three RyR isoforms, encoded by separate genes sharing a high level of homology, have been identified in mammalian tissues. Ryanodine receptor type 1 (RyR1) is the primary isoform expressed in skeletal muscle. RyR1 is also expressed in some areas of the central nervous system and in some haemopoietic cells. RyR2 is the predominant isoform in cardiac muscle and is expressed in various regions of the brain whereas RyR3 has widespread expression, particularly during development. In skeletal muscle, RyR1 is a key protein involved in excitation-contraction (EC) coupling. In a simplified overview of this process, an electrical signal generated by an action potential travelling along the transverse $(\mathrm{t})$-tubules is detected by the dihydropyridine receptor (DHPR), a voltage-sensitive $\mathrm{Ca}^{2+}$ channel. In response to membrane depolarization, DHPR channels undergo a conformational change and induce the opening of RyR1 channels that are closely apposed and located on the SR terminal cisternae. This leads to the release of $\mathrm{Ca}^{2+}$ from SR stores into the cytoplasm. The cytoplasmic $\mathrm{Ca}^{2+}$ binds to troponin and initiates muscle contraction in sarcomeres. Muscle contraction is terminated upon closure of RyR1 and reuptake of $\mathrm{Ca}^{2+}$ from the cytoplasm into the SR by sarcoplasmic/endoplasmic $\mathrm{Ca}^{2+}$ ATPase (SERCA) pumps.

Ablation of RyR1 in mice (dyspedic mice) results in a lethal phenotype most likely due to respiratory failure. Mutant neonates also display skeletal abnormalities, including spined curvature, arched vertebral column, thin limbs and a thick neck, and resembled dysgenic mice that lack DHPR [1]. Primary dyspedic muscle cell cultures exhibit severely impaired $\mathrm{Ca}^{2+}$ release after depolarization, demonstrating the pivotal role RyR1 plays in skeletal muscle EC coupling. Over the 
past decades it has emerged that, mutations in RYR1 are a major cause of muscle disease. Both dominant and recessive mutations have been identified throughout the $R Y R 1$ coding sequence and are responsible for a wide range of muscle disorders including malignant hyperthermia ( $\mathrm{MH}$ ), central core disease (CCD), multi-minicore disease, centronuclear myopathy, core-rod myopathy and congenital fiber type disproportion (Box 1) [2-4]. Dantrolene, used in the emergency treatment of malignant hyperthermia, is currently the only clinically relevant drug for RyR 1 disorders and drugs that address the chronic, often life-threatening muscle weakness associated with many RyR1 disorders are much needed.

The aim of this review is to summarize the current understanding of RyR1 structure and function and, in particular, the domains that mediate RyR1-protein and RyR1-ion interactions, which finely regulate channel function. The interactions of RyR1 with a host of modulators, such as the dihydropyridine receptor (DHPR), FKBP12, homer, calmodulin, S100A1, and calcium have been well studied and are summarized in Tables 1 and 2 and Figure 1. By comparing this information with recently reported recessive mutations, it can be seen that many of these mutations fall within RyR1 protein binding domains, leading to the hypothesis that abnormal RyR1-protein interactions may be an underlying cause of ryanodine receptor malfunction and disease (Table 3).

\section{Structure of the ryanodine receptor}

The ryanodine receptor is the largest known ion channel and forms a homotetrameric structure of approximately 2.3 MDa. Each 565-kDa monomeric subunit consists of 5038 amino acids. Approximately four-fifths of the channel is made up of the large $\mathrm{N}$-terminal cytoplasmic domain, which contains binding sites for a number of modulators. The C-terminal region contains the transmembrane domains and ion-conducting pore. RyR1 is characterized by a very largeconductance with moderate selectivity for divalent cations over monovalent cations [5]. The selectivity filter contains a widely conserved sequence (Gly-X-Arg-X-Gly 3 -X-Gly-Asp) found in several different cation channels, including potassium channels and IP $\mathrm{P}_{3} \mathrm{Rs}$. Aspartate 4900 and glycine within the RyR1 motif 4895Glys-lle-Gly-Asp are particularly important for ion selectivity (unless otherwise indicated all amino acid numbers refer to the human sequence)[6, 7]. Figure 2 illustrates the overall structural information of the RyR1, including the distinct cytoplasmic and transmembrane assemblies. For detailed reviews, see $[8,9]$. 
Interdomain Interactions

Cryo-electron microscopy (cryo-EM) studies indicate that the RyR undergoes widespread long-range conformational changes during the transition from closed to open states and that binding of various modulators increases the probability of the 'on' or 'off' state [10-12]. A domainswitch hypothesis has been proposed to explain the transition between 'on' and 'off' states [13], whereby several subdomains throughout the $\mathrm{MH} / \mathrm{CCD}$ hotspots $\mathrm{N}$-terminal domain 1 (amino acids 35-614) and the central domain 2 (amino acids 2163-2458) interact to stabilize the basal closed conformational state (Figure 3). Upon activation, the interdomain interactions are disrupted, leading to a conformational change in which the channel 'opens'. Perturbation of the interdomain interactions with a monoclonal antibody against the $\mathrm{N}$-terminal domain 1 results in RyR1 channel activation [14]. Interestingly, many pathogenic dominant RyR1 mutations associated with $\mathrm{MH}$ fall within $\mathrm{MH} / \mathrm{CCD}$ hotspots of domains 1 and 2. It is thought that some of the mutations associated with $\mathrm{MH}$ weaken interdomain interactions and decrease the energy barrier required for channel opening, resulting in hypersensitive channels [15].

\section{Alternative Splicing}

Analysis of rabbit RyR1 cDNA reveals two alternatively spliced regions that likely modulate RyR1 channel properties by altering interdomain interactions or interactions with other proteins. Exclusion of exon 70 results in the ASI(-) RyR1 isoform, lacking five residues (3481-3485), and the exclusion of exon 83 results in the ASII(-) isoform, which also lacks five residues (3865-3870) [16]. There is conflicting data on whether variant expression is tissue-specific and developmentally regulated. Zorzato and colleagues reported that both AS variants are found in fast- and slowtwitch rabbit skeletal muscles irrespective of their developmental stage [17], whereas others have shown that the ASI(-)/ASII(-) forms predominate during early development and the ASI(+)/ASII(+) forms predominate in adulthood $[16,18]$. Abnormal overexpression of the ASI(-) isoform of RyR1 occurs in myotonic dystrophy type 1 and may contribute to muscle dysfunction [18].

Data describing the functional consequences of expressing alternatively spliced variants is inconclusive. Peptide studies suggest that the ASI region together with an adjacent basic amino acid sequence (the combined region Thr3471-Gly3500) are involved in interdomain interactions that stabilize the closed channel conformation, and that the ASI(-) variant stabilizes the closed channel more effectively [19]. Less is known about the function of the ASII region. Both alternatively spliced sequences sit within a broader region encompassing: (i) a calmodulin binding 
region and (ii) the Arg-Gly-Asp (RGD) adhesive sequence, a well-established protein-binding motif; [16].

\section{Interactions with Cytoplasmic Protein Modulators}

RyR1 interacts with a large number of proteins and ionic modulators. Some protein partners have been investigated in detail and their corresponding binding sites on RyR1 determined with confidence whereas details for others are sparse and uncertain.

\section{Dihydropyridine Receptor (L-type $\mathrm{Ca}^{2+}$ channel)}

In skeletal muscle, there is a regular geometric arrangement of RyR1 and DHPR channels in which alternate RyR1 channels associate with four DHPR channels [5]. This close association permits direct signalling between the $\mathrm{DHPR}_{1.1}$ and RyR1 both in the forward direction (orthograde signalling in which DHPR activation causes the RyR1 to open) and retrograde signalling (whereby RyR1 interactions enhance current through the DHPR channel) $[20,21]$. DHPRs are composed of 5 subunits The $\alpha_{1.1}$ subunit contains the voltage sensor, forms the pore region of the channel, and is believed to be one of the main sites of interaction with RyR1, though recent research supports the importance of other sites [21, 22]. Specifically, there is good evidence that the $\alpha_{1.1}$ II-III loop (between the second and third transmembrane domains of the $\alpha_{1.1}$ subunit) and the $\beta_{1 \mathrm{a}}$ subunit bind to different regions of RyR1.

Although experiments using RyR1/RyR2 chimeras and RyR1 peptide fragments have sometimes yielded contrasting results [21, 23-27], current evidence implicates the SPRY2 domain, located in the $\mathrm{N}$-terminal cytoplasmic region of RyR1. SPRY domains are protein-protein interaction motifs defined by a characteristic pattern of $\beta$-sheets. The RyR 1 isoform has three highly conserved SPRY domains (Table 2). Interestingly, cryo-EM mapping of the SPRY2 domain reveals that its location on the RyR1 overlaps with the previously proposed positioning of DHPR [28]. In vitro studies indicate that the SPRY2 region binds the DHPR $\alpha_{1.1}$ II-III loop [27, 29] and may also participate in an interdomain interaction within RyR1 [19], binding to the broader ASI region via the positive amino acid cluster Lys3495-Arg3502, which is homologous to a similar sequence on the II-III loop of the DHPR $\alpha_{1.1}$ subunit. The physiologic importance of this SPRY2/ASI interaction is currently uncertain, as are the roles of the SPRY1 and SPRY3 domains.

Aside from the $\alpha_{1.1}$ subunit, there is good evidence that RyR1 also directly interacts with the $\beta_{1 a}$ subunit (Table 2 ) $[22,30]$ and that the strength of this interaction is governed by the 
positively charged motif Lys(3495)-Lys-Lys-Arg-Arg-Gly-Asp-Arg(3502) [30]. The $\beta_{1 a}$ subunit may play a dual role in augmenting EC coupling, both by activating RyR1 during EC coupling, and by targeting the DHPR to precisely aligned tetrad arrays on the t-tubules that oppose the RyR1 complex (reviewed in [31]).

Early studies implicated other RyR1 regions in DHPR interactions but the domains are large and their importance is uncertain. The second of three divergent regions (D1-D3), so named because the sequences represent areas of variance between RyR isoforms, has been proposed as a DHPR binding site because the presence of residues 1272-1455 (region D2) rescues skeletal-type EC coupling [21, 32,33], whereas deletion of this region abolished this coupling [34]; however, other studies dispute this finding [35]. In addition, D2 has been shown to be critical in the formation of DHPR tetrads [21]. Experiments using chimeric RyR containing segments of different isoforms (ie: RyR1/RyR2 or RyR1/RyR3 chimera) suggest that RyR1 residues 1837-2168 (rabbit CDNA), contribute to both EC coupling and calcium release and residues 2659-3720 may be important in retrograde signalling $[25,35]$.

\section{Calmodulin (CaM)}

Calmodulin is a ubiquitously expressed, highly-conserved, 17-kDa protein that binds the cytoplasmic surface of the ryanodine receptor and modulates its activity in a complex manner. Four calmodulin molecules bind per RyR subunit. Calmodulin differentially regulates RyR1 activity depending on whether or not it has $\mathrm{Ca}^{2+}$ bound. In its $\mathrm{Ca}^{2+}$-free state (apoCaM), it is a weak partial agonist whereas the $\mathrm{Ca}^{2+}$-bound form ( $\mathrm{CaCaM}$ ) is a stronger antagonist of RyR calcium release [36]. Thus, calmodulin likely acts as a cytoplasmic calcium sensor for RyR. It may also affect channel activity by influencing binding to DHPR (which binds RyR1 in close spatial proximity) or by affecting RyR1 interdomain interactions [37, 38].

Calmodulin binding sites on RyR1 have been extensively researched and although a number of different sequences have been proposed based on the experimental protocols used, there is some consensus regarding the importance of particular sequences (Figures 1 and 2, Table 2). Although apoCaM and CaCaM bind to distinct domains of RyR1, some studies show that residues 3614-3643 and 2937-3225, among others, bind both forms of calmodulin [39-42]. There is evidence that CaCaM binds residues 3553-3662 and 4303-4431 [40, 41]. More recent data also suggests that the $\mathrm{N}$-terminus of calmodulin interacts with sequence 1975-1999 [43]. Interestingly, residues 1975-1999 and 3614-3643 are likely to be in close proximity in the three-dimensional 
1 RyR1 structure which would make it feasible for one CaM molecule to bind both sites 2 simultaneously [43].

Like calmodulin, the S100 proteins are cytoplasmic calcium-binding proteins containing two EF-hand motifs. S100A1 is one of at least 21 different S100 isoforms expressed in humans, and is most highly expressed in cardiac and skeletal muscle where it regulates SR calcium release and mitochondrial function. There is reasonable consensus regarding the S100A1 binding domains on RyR1 (Figure 1 and Table 2). Competition assays using CaCaM and binding experiments with RyR1 peptides defined residues $3616-3627$ as the $\mathrm{Ca}^{2+}{ }^{2+}$ S100A1 binding site and show that $\mathrm{Ca}^{2+}{ }^{2+S 100 A 1}$ likely competes with CaCaM for this binding domain [44]. This finding is not surprising, as S100A1 proteins and calmodulin bind similar structural motifs in other proteins. The physiological consequence of the competitive binding of S100A1 and calmodulin to RyR is not well understood.

Physiologically relevant concentrations of S100A1 can activate RyR1 in vitro. When applied to purified RyR1 channels reconstituted in lipid bilayers, S100A1 enhances the normalized open probability of RyR1 at $\mathrm{nM}$ calcium concentrations [45]. S100A1 -/- knockout mice and mice containing a mutation in the S100A1 binding domain on RyR1 exhibit reduced SR calcium release, reduced global cytoplasmic calcium transients, and reduced force generation [46-48]. Further experiments suggested that the S100A1 protein is important in activating RyR1 in response to a single action potential $[47,48]$. With repetitive action potentials, S100/CaM binding may have an inhibitory effect because mouse muscles carrying a mutation that eliminates S100/CaM binding showed increased SR calcium release when stimulated at $100 \mathrm{~Hz}$ [48].

In addition to residues 3616-3627, initial studies that measured the ability of digoxigeninlabelled S100A1 to bind RyR1 found evidence for three other binding regions (amino acids 1861$2155,3773-3873$, and 4426-4622) [45].

FKBP12 (also known as FK506BP, calstabin)

The FK506-binding proteins (FKBPs) are immunophilins, a family of highly conserved proteins that bind immunosuppressive drugs, such as FK506 (tacrolimus). FKBPs are expressed in most tissues and are involved in a variety of cellular processes including protein folding, receptor signalling, and transcription. Two isoforms, FKBP12 and FKBP12.6 (also known as calstabin 1 and 2, respectively) can interact with all three RyR isoforms, but likely have distinct roles owing to 
different binding affinities and patterns of tissue expression. Specifically, FKBP12 is the predominant isoform expressed in skeletal muscle [49], whereas FKBP12.6 co-purifies with RyR2 in the heart.

In normal skeletal muscle, FKBP12 binds to the cytoplasmic side of RyR with high affinity and stabilizes the closed conformation. Experiments using immunosuppressive drugs that disrupt FKBP12 binding to RyR and FKBP-deficient mice have shown that loss of FKBP binding increases the open probability of the ryanodine receptor and induces the appearance of sub-conductance states of the channel $[50,51]$. In addition to inhibiting RyR, FKBP12 likely influences EC coupling by modifying orthograde signalling and possibly retrograde signalling between RyR1 and DHPR [5254]. FKBP12 has also been implicated in coordinating gating between adjacent RyR molecules, which results in neighbouring channels opening simultaneously in response to a voltage change [55].

Four FKBP12 molecules can bind to one ryanodine receptor tetramer and threedimensional cryo-EM difference mapping and FRET studies have revealed that the FKBP12 binding site is close to the clamp domain $[56,57]$. A study that mapped four particular mutations (human residues Glu160, Arg163, Arg401, and Ile403) known to cause malignant hyperthermia and central core disease onto the cryo-EM RyR1 structure suggest that the mutations may reside within the FKBP12 binding region [58], but this has not been experimentally confirmed. Several lines of evidence implicate residues 2458-2468 as an important FKBP12 binding site on RyR1 with amino acid 2461 being particularly important [53].

\section{Interactions with SR Luminal Proteins}

The ryanodine receptor is also modulated by proteins that reside in the SR lumen, primarily triadin, junctin and calsequestrin (CSQ), which likely function in a coordinated manner.

\section{Triadin and Junctin}

Triadin and junctin are two SR luminal proteins that interact with RyR to regulate its function. Both are integral SR membrane proteins with similar features, such as a short cytoplasmic $\mathrm{N}$-terminal tail, a single transmembrane domain, and a longer $\mathrm{C}$-terminal tail that extends into the SR lumen. The C-terminal tails of both proteins contain multiple clusters of alternating lysine and glutamic acid residues (KEKE motifs) that likely bind CSQ and possibly RyR as 
well $[59,60]$. Recent research emphasizes the importance of RyR2-triadin interactions for channel function in the heart. In skeletal muscle, triadin knockdown affects voltage-dependent calcium release and reduces muscle function $[61,62]$, whereas disruption of triadin binding reduces both voltage- and ligand-gated SR calcium release, suggesting that triadin may play a role in skeletal muscle EC coupling [63]. The primary triadin binding site on RyR1 has determined by in vitro binding and site-directed mutagenesis is the second intraluminal loop of RyR1 (residues 48614918). In particular, three acidic residues (Asp4879, Asp4908, and Glu4909) are particularly important [60]. The second intraluminal loop may also contain the pore and selectivity filter of the calcium channel. A number of dominant RYR1 mutations found in patients with central core disease fall within the triadin binding domain, but their effects on protein-protein interaction have not been investigated.

It has been suggested that junctin may be the main protein mediator between CSQ and RyR [64]. Knockdown of junctin in myotubes reduces both depolarization-induced SR $\mathrm{Ca}^{2+}$ release and reduced SR $\mathrm{Ca}^{2+}$ stores [61], possibly by disrupting the signalling complex between CSQ and RyR. The role of junctin in maintaining $S R \mathrm{Ca}^{2+}$ stores as well as its binding site on RyR1 remain uncertain.

\section{Calsequestrin (CSQ)}

CSQ is the primary calcium-binding protein in the SR lumen and its high-capacity/lowaffinity binding properties for calcium ions make it a highly effective calcium storage protein, with around 40-50 calcium ions bound per CSQ molecule in skeletal muscle [65]. Though in vitro studies demonstrate the ability of CSQ to bind directly to RyR1, it is uncertain whether this occurs in vivo or if CSQ interacts with RyR through triadin/junctin interactions [66]. Purified RyR channels freed from triadin and junctin were not inhibited in response to exogenous CSQ, suggesting that CSQ does not bind directly to RyR1 [67].

\section{Other Potential Protein Modulators}

A number of other potential protein modulators of the RyR1 channel have been discovered but the specific RyR1 binding sites are currently undefined for these proteins.

\section{Calcium Homeostasis Endoplasmic Reticulum Protein (CHERP)}


CHERP is a recently identified integral SR/ER membrane protein shown to interact with RyR1 through pull-down and co-localization studies [68]. CHERP participates in cytosolic $\mathrm{Ca}^{2+}$ cycling within cells and affects diverse cellular processes, such as DNA synthesis, growth and proliferation [69]. siRNA-mediated suppression of CHERP expression in HEK-293 cells transfected with the full-length RyR1 resulted in decreased calcium flux through the ryanodine receptor [68] but further work is required to confirm that CHERP is a direct binding partner of RyR1 in vivo and to clarify its physiological role.

\section{Homer/Ves1}

Homer proteins are high-affinity ligands that modify RyR channel function. Within neurons and other tissues, homer proteins are important anchoring or adaptor proteins that facilitate the formation of multimeric protein complexes [70]. Homer may play a similar role in the SR by stabilizing interactions between RyR1 and possibly DHPR. Different homer isoforms (e.g. 1b, 1c, and 2b) activate RyR1 in single-channel experiments, induce calcium release from SR vesicles, and increase the frequency of calcium sparks from permeabilized skeletal muscle fibers (reviewed in [71]).

Homer proteins contain EVH1 domains that facilitate binding to proline-rich consensus sequences on target proteins, defined by Pro-Pro- $X-X-\phi$ (where $X=a n y$ amino acid and $\phi=$ aromatic residue), flanked by charged residues [71]. There are many homer consensus sequences in RyR1 (Figure 1 and Table 2).

\section{Selenoprotein}

Selenoproteins contain a selenocysteine residue (a modified cysteine residue where selenium replaces the sulphur moity), and are implicated in diverse processes that capitalize on the high redox potential of the selenium ion. One study demonstrated that selenium compounds induce calcium release from SR vesicles, affect ryanodine binding at varying concentrations, and stimulate or inhibit RyR by binding free thiols within the protein [72]. Selenoprotein N (SeIN) is a SR transmembrane protein found to be associated with RyR1 in vivo and required for normal muscle development and differentiation in zebrafish muscle [73]. When SelN is absent, RyR loses its normal sensitivity to redox modulation [73]. Mutations in SEPN1, which encodes SelN, cause a skeletal myopathy with many histological and phenotypic similarities to RYR1-related multiminicore disease and it is hypothesized that the disease mechanism may involve abnormal redox 
status and function of RyR1 [74]. It has not yet been clarified whether SelN and RyR1 interact directly and, if they do, the binding sites that are involved.

\section{Interactions with Ions and Small Molecular Modulators}

Aside from protein ligands, the ryanodine receptor is also regulated by several ions and small molecules, including calcium, magnesium, and ATP. Calcium and magnesium, in particular, likely interact at numerous sites to influence channel function.

\section{Calcium $\left(\mathrm{Ca}^{2+}\right)$}

$\mathrm{Ca}^{2+}$ modulates RyR1 function both directly and indirectly through interactions with both the cytoplasmic and SR luminal surfaces of RyR1. The indirect effect is mediated primarily by calmodulin and CaMKII, but also via S100A1, triadin, junctin, and calsequestrin (discussed above). The direct effects of calcium on channel function are discussed in this section.

The $\mathrm{Ca}^{2+}$ concentration in the SR lumen may directly modulate calcium release from RyR1. In lipid bilayer single channel experiments as the SR lumen $\mathrm{Ca}^{2+}$ levels are increased there is an enhanced sensitivity of RyR1 to cytosolic agonists, such as caffeine and ATP [75-77]. However, it remains uncertain whether there are specific $\mathrm{Ca}^{2+}$-binding sites on the SR luminal face of RyR1 or whether $\mathrm{Ca}^{2+}$ can modulate activity by passing through the channel pore and binding to sites on the cytoplasmic surface. Recent evidence suggests the presence of luminal sites in RyR2 [78, 79].

RyR1 activity exhibits a bell-shaped dependence on cytoplasmic $\mathrm{Ca}^{2+}$ arising from the binding of $\mathrm{Ca}^{2+}$ to two distinct classes of binding sites: low $\left[\mathrm{Ca}^{2+}\right]$ bind to high-affinity activation sites and high $\left[\mathrm{Ca}^{2+}\right]$ bind to low-affinity inactivation sites. Evidence suggests that the $\mathrm{C}$-terminal third of RyR1 contains several important high-affinity $\mathrm{Ca}^{2+}$-binding sites [80]. Polyclonal antibodies raised against residues 4380-4625 inhibit $\mathrm{Ca}^{2+}{ }^{2}$-induced calcium release from isolated SR [81]. Overlay studies and site-directed polyclonal antibodies indicate $\mathrm{Ca}^{2+}$-binding residues at 4245 4378 and 4479-4515 [82]. A negatively charged Pro-Glu repeat sequence (PEPEPEPEPEPE) at residues 4490-4502 is likely the critical $\mathrm{Ca}^{2+}$-binding domain in this region because antibodies raised against this sequence inhibit $\mathrm{Ca}^{2+}$-dependent RyR1 activation [83]. Site-directed mutagenesis provides evidence for physiologically-important calcium-binding at human RyR1 residue Glu4031 (equivalent to rabbit RyR3 residue Asp3885) [84]. The RyR1 likely has other highaffinity $\mathrm{Ca}^{2+}$-binding sites that have yet to be identified. 
Less is known about the low-affinity $\mathrm{Ca}^{2+}$-inactivation sites and the available data is contradictory. A truncated RyR channel lacking residues 1-3660 failed to close at high $\left[\mathrm{Ca}^{2+}\right]$, which may indicate that $\mathrm{Ca}^{2+}$ inactivation sites are located in the $\mathrm{N}$-terminal foot of the protein [85]; however, the absence of such a large portion of the protein likely affects the overall structure of the RyR1. Other studies suggest the importance of the C-terminus for inactivating $\mathrm{Ca}^{2+}$-binding sites. Indeed, RyR1/RyR2 chimeras containing an RyR2 C-terminal domain show reduced inhibition of the channel at elevated $\mathrm{Ca}^{2+}$ levels, suggesting that the C-terminal region (residues 3726-5038) contains important $\mathrm{Ca}^{2+}$-inactivation sites [86]. Specifically, mutation of a putative EF handhomology region (4080-4091) greatly enhances channel activity, supporting the idea that this region is an important calcium-inactivation site [87]. Other possible $\mathrm{Ca}^{2+}$-inactivation sites have been identified throughout the RyR1 protein sequence such as between residues 4063-4209 [88].

\section{Magnesium}

The effect of magnesium on channel function is intimately linked to $\mathrm{Ca}^{2+}$ levels. Based on single channel experiments and studies of calcium release from SR vesicles, there is good evidence that $\mathrm{Mg}^{2+}$ competes with $\mathrm{Ca}^{2+}$ for the high-affinity $\mathrm{Ca}^{2+}$-activation binding sites and prevents channel activation. A second likely mechanism involves the low-affinity $\mathrm{Ca}^{2+}$-inactivation binding sites, which are less-selective to divalent ions and permit $\mathrm{Mg}^{2+}$ to inhibit channel function [89]. It was recently shown that the relative concentrations of SR luminal $\mathrm{Ca}^{2+}$ and $\mathrm{Mg}^{2+}$ play an important role in determining the unitary calcium current amplitude through the RyR pore. As the $\mathrm{SR} \mathrm{Mg}^{2+}$ load increases the open probability decreases, leading to lower intracellular calcium levels [90]. The current model predicts that the $\mathrm{Mg}^{2+}$ binding sites on RyR1 overlap with those for $\mathrm{Ca}^{2+}$.

Overall, ATP is an activator of RyR1 but the strength of its effects depends on the concentration of $\mathrm{Ca}^{2+}, \mathrm{Mg}^{2+}$ and other exogenous modulators that may modify the number of accessible ATP binding sites [91, 92]. In $\left[{ }^{3} \mathrm{H}\right]$ ryanodine binding and single channel measurements, ATP only minimally activates the channel at low $\mathrm{Ca}^{2+}$ concentrations and $\mu \mathrm{M} \mathrm{Ca}^{2+}$ is required for maximal activation of RyR by ATP [91]. Other adenine nucleotides, such as AMP and adenosine, are even weaker RyR1 agonists. 
Based on a proposed nucleotide binding motif, there are several possible ATP binding sites on RyR1. Photoaffinity labelling has confirmed possible ATP-binding regions [93]; however, further resolution of these segments is required.

\section{NADH and NADH Oxidase}

Cyclic adenosine diphosphate (CADP) ribose and nicotinamide-adenine dinucleotides $\left(\mathrm{NAD}^{+} / \mathrm{NADH}\right)$ modulate RyR function in an isoform specific way. cADP ribose increases $\mathrm{Ca}^{2+}$ transients through RyR1, either by acting directly on the receptor or by affecting ancillary protein binding partners [94]. NAD species $\left(\mathrm{NAD}^{+} / \mathrm{NADH}, \mathrm{NADP} / \mathrm{NADPH}\right)$ are redox-based signalling molecules affecting a wide range of biological pathways. Direct redox modulation of reactive thiol groups on the RyR has been described (see "Redox Modulation" section), but the mechanism by which NAD species affect RyR channel function may be isoform-specific. Some studies demonstrate that both NAD+ and NADH activate RyR1 $[95,96]$, while others found that NADH has minimal effects [97]. NAD species may influence RyR1 activity through several mechanisms. $\mathrm{NAD}^{+} / \mathrm{NADH}$ may interact directly with RyR1 at ATP-binding sites due to structural similarities between these two molecules [95]. An NADH-dependent oxidase (NOX) present in the SR membrane interacts with RyR1 and reduces reduced oxygen to superoxide, which in turn activates RyR1 [96]. In addition, a potential oxidoreductase-like domain is present in the N-terminus of RyR1 (residues 40-419) that may bind $\mathrm{NAD}^{+}$and act as a redox sensor discussed in [58].

\section{Posttranslational Modification of the Ryanodine Receptor}

The ryanodine receptor undergoes posttranslational modification through a range of physiologic processes such as phosphorylation, oxidation, and nitrosylation, all of which may be elicited by stress-dependent signalling pathways [98]. The effects of these modifications on the ryanodine receptor are complex and controversial, but recent studies are beginning to clarify this field.

\section{Kinases and Phosphatases}

The ryanodine receptor can be phosphorylated and dephosphorylated by a range of

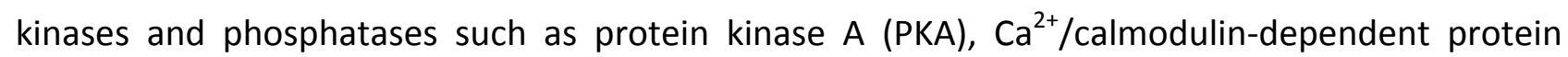
kinase II (CaMKII), cGMP-dependent kinase, and protein phosphatase (PP) [99-102]. The largest 
body of data relates to RyR2 in cardiac muscle. Most studies indicate that phosphorylation by PKA, which is activated by $\beta$-adrenergic signals, activates $\mathrm{RyR} 2$ and $\mathrm{Ca}^{2+}$ release, thereby inducing a positive inotropic effect on the heart [103]. Initial studies in skeletal muscle found variable effects of phosphorylation on channel activity, but there is an emerging consensus that phosphorylation by PKA or CAMKII activates RyR1 [100, 104, 105].

There is good evidence that interactions between RyR and various kinases and phosphatases require binding of specific targeting proteins to highly conserved leucine/isoleucine zipper (LIZ) motifs located on RyR channels [106]. These LIZ motifs interact with targeting proteins, such as muscle A-kinase anchoring protein (mAKAP) and spinophilin, which localize specific kinases and phosphatases, such as PKA and protein phosphatase I (PPI) respectively, to the RyR. Although these results were first demonstrated for the RyR2 macromolecular complex, the RyR2 LIZ motifs that bind PKA and PPI are highly conserved in RyR1. RyR1 residues 553-602 co-precipitated with PPI and residues 3039-3075 co-precipitated with PKA [106]. A consensus sequence (Arg-His-Arg(Val)-Ser-Leu) within the calmodulin binding domain also binds PKA (residues 3051-3056) and Ser3055 is the likely phosphorylation target [107]. Ser3055 phosphorylation is inhibited when calmodulin binds RyR1 and the binding of calmodulin is inhibited by Ser3055 phosphorylation.

Phosphorylation of Ser2843 occurs in vivo and there are several further potential phosphorylation consensus sites in RyR1 that require confirmation (Figure 1). Phosphorylation at Ser2843 may increase the sensitivity of RyR1 to cytoplasmic $\mathrm{Ca}^{2+}$ and promote release of FKBP from RyR1 thereby destabilizing the closed conformation [103] but other studies challenge this finding [108].

\section{Redox Modulation}

It is well-established that RyR channel function is altered by reversible redox processes, such as cysteine (disulphide) oxidation, S-nitrosylation, and S-glutathionylation. Abnormal oxidation of RyR1 has been implicated in several disease states, such as muscular dystrophy and heart failure $[98,109]$ but a detailed understanding is lacking.

Reactive oxygen species and reactive nitrogen species are continuously generated within active skeletal muscle and can modulate muscle function. RyR1 is a major cellular redox sensor in skeletal muscle, having $\sim 100$ cysteine thiol groups on its surface. Three general classes of thiols are proposed: (i) most are likely inert and resist oxidation during normal activity; (ii) 6-8 thiol groups are hyper-reactive and sensitive to the local oxidative environment, modulating RyR1 channel 
1 function in conditions of moderate oxidative stress such as during vigorous exercise; and (iii) thiols

2 that can be oxidized by extreme oxidative stress, impairing RyR channel function [110]. Some redox-active cysteines in RyR1 are located in calmodulin- and FKBP12-binding regions [111], and changes in binding affinity for these effectors is one way that the oxidative environment modulates RyR1 function [109].

As a general rule, oxidizing reagents activate and reducing reagents inhibit RyR channel activity [112]. In vitro RyR1 activity is increased by many oxidizing species, including superoxide anion, hydrogen peroxide, hydroxyl radicals and nitric oxide although channel function is inhibited in extreme oxidative environments. The relationships between redox state, other factors such as membrane potential or the concentrations of RyR1 protein modulators, and channel function are extremely complex and beyond the scope of this article.

There is little consensus on the location of the specific cysteine residues that are redoxactive. Cysteine residues at positions $35,314,810,905,1039,1302,1590,2326,2363,2436,2565$, 2606, 2611, 3193 and 3635 have been implicated in at least one study [113, 114]. Cys3635 has been confirmed as redox-sensitive in two studies and has been implicated in voltage-gated EC coupling and regulation of calmodulin binding $[43,115]$.

\section{Using information about RyR1 functional domains to understand disease pathogenesis}

As an example of how information on RyR1 functional domains can be used to investigate the possible disease mechanisms, we have analyzed a range of myopathy cases caused by recessive RYR1 mutations (Table 3). Some patients are compound heterozygous for two different missense mutations, but interestingly, over half of patients are compound heterozygous for a missense mutation and a 'null' mutation (including protein-truncation mutations or frameshift/splice-site mutations that disrupt the reading frame). Such 'null' mutations likely abolish protein expression from that allele and the phenotype is probably determined primarily by the sequence variant on the other RYR1 allele (carrying the missense mutation). Analysis of these missense mutations can give insights into disease pathogenesis. For example, the Arg2435Leu mutation changes a conserved arginine residue that likely alters the redox-sensing properties of Cys2436. Three mutations, His2035Leu, Arg3772GIn and Arg3772Trp sit within or immediately adjacent to S100A1 binding domains and the changes in surface charge may alter S100A1-RyR1 
interactions. In this way, in-silico analysis of different mutations can generate hypotheses that can inform research into disease pathogenesis.

\section{Concluding Remarks}

(1)

After reviewing the existing knowledge about the structure of RyR1 and the relationship to its function, it is clear there is much left to discover. For most parts of the protein, it remains uncertain how the amino acid sequences fold to form the tertiary protein structure and the role of specific residues in specific channel functions is based on partial information. Achieving a crystal structure for the full tetrameric complex will be a major milestone for the field and for understanding the molecular basis of various channel properties. It is also clear that our current knowledge of how channel function is modulated by various interacting proteins and small molecules is rudimentary. Many other interacting proteins likely remain undiscovered and the RyR1 binding sites for many recognized interacting proteins are uncertain. Advancing this field is not only important for understanding normal skeletal muscle function, but will influence the treatment of many muscle disorders. Drugs can now be designed to modulate specific molecular interactions and the potential to normalize RyR1 function using small molecules in primary RYR1myopathies and other skeletal muscle disorders is great. At present this a distant goal but we hope that consolidating our knowledge of the functional domains of RyR1 is a useful early step on this journey. We also hope that it helps the investigation of the ways that different RYR1 mutations cause muscle dysfunction and directs us to the most fruitful areas for therapy development.

\section{Acknowledgements}

This work was supported by the National Health \& Medical Research Council (NC; grants 1035828 \& 1022707), the Swiss National Science Foundation (SNF 310030-129785), the Association Française contre les Myopathies (AFM), and the Albert Einstein College of Medicine Senior Research Fellowship.

\section{References}

1 Takeshima, H., et al. (1994) Excitation-contraction uncoupling and muscular degeneration in mice lacking functional skeletal muscle ryanodine-receptor gene. Nature 369, 556-559

2 Treves, S., et al. (2008) Congenital muscle disorders with cores: the ryanodine receptor calcium channel paradigm. Curr. Opin. Pharmacol. 8, 319-326 
3 Clarke, N.F., et al. (2010) Recessive mutations in RYR1 are a common cause of congenital fiber type disproportion. Hum. Mutat. 31, E1544-E1550

4 Wilmshurst, J., et al. (2010) RYR1 mutations are a common cause of congenital myopathies with central nuclei. Ann. Neurol. 68, 717-726

5 Fill, M. and Copello, J.A. (2002) Ryanodine receptor calcium release channels. Physiol. Rev. 82, 893-922

6 Zhao, M., et al. (1999) Molecular identification of the ryanodine receptor pore-forming segment. J. Biol. Chem. 274, 2597125974

7 Gillespie, D., et al. (2005) (De) constructing the ryanodine receptor: Modeling ion permeation and selectivity of the calcium release channel. J. Phys. Chem. B 109, 15598-15610

8 Ramachandran, S., et al. (2009) A structural model of the pore-forming region of the skeletal muscle ryanodine receptor (RyR1). PLoS Comput. Biol. 5, e1000367

9 Van Petegem, F. (2012) Ryanodine Receptors: Structure and Function. J. Biol. Chem.

10 Serysheva, I., et al. (1999) Structure of the skeletal muscle calcium release channel activated with Ca2+ and AMP-PCP.

Biophys. J. 77, 1936-1944

11 Ikemoto, N. and Yamamoto, T. (2000) Postulated role of inter-domain interaction within the ryanodine receptor in Ca2+ channel regulation. Trends Cardiovasc. Med. 10, 310-316

12 Sharma, M.R., et al. (2000) Three-dimensional structure of ryanodine receptor isoform three in two conformational states as visualized by cryo-electron microscopy. J. Biol. Chem. 275, 9485-9491

13 Ikemoto, N. and Yamamoto, T. (2002) Regulation of calcium release by interdomain interaction within ryanodine receptors. Front. Biosci. 7, d671-d683

14 Zorzato, F., et al. (1996) Role of malignant hyperthermia domain in the regulation of Ca2+ release channel (ryanodine receptor) of skeletal muscle sarcoplasmic reticulum. J. Biol. Chem. 271, 22759-22763

15 Bannister, M.L., et al. (2007) Malignant hyperthermia mutation sites in the Leu2442-Pro2477 (DP4) region of RyR1 (ryanodine receptor 1 ) are clustered in a structurally and functionally definable area. Biochem. J. 401, 333-339

16 Futatsugi, A., et al. (1995) Tissue-specific and developmentally regulated alternative splicing in mouse skeletal muscle ryanodine receptor mRNA. Biochem. J. 305, 373-378

17 Zorzato, F., et al. (1994) Identification of two ryanodine receptor transcripts in neonatal, slow-, and fast-twitch rabbit skeletal muscles. Biochem. Biophys. Res. Commun. 203, 1725-1730

18 Kimura, T., et al. (2005) Altered mRNA splicing of the skeletal muscle ryanodine receptor and sarcoplasmic/endoplasmic reticulum Ca2+-ATPase in myotonic dystrophy type 1. Hum. Mol. Genet. 14, 2189-2200

19 Kimura, T., et al. (2007) A variably spliced region in the type 1 ryanodine receptor may participate in an inter-domain interaction. Biochem. J. 401, 317-324

20 Nakai, J., et al. (1996) Enhanced dihydropyridine receptor channel activity in the presence of ryanodine receptor. Nature 380, 72-75

21 Sheridan, D.C., et al. (2006) Bidirectional signaling between calcium channels of skeletal muscle requires multiple direct and indirect interactions. Proc. Natl. Acad. Sci. U.S.A. 103, 19760-19765

22 Rebbeck, R.T., et al. (2011) The beta(1a) subunit of the skeletal DHPR binds to skeletal RyR1 and activates the channel via its 35-residue C-terminal tail. Biophys. J. 100, 922-930

23 Leong, P. and MacLennan, D.H. (1998) A 37-amino acid sequence in the skeletal muscle ryanodine receptor interacts with the cytoplasmic loop between domains II and III in the skeletal muscle dihydropyridine receptor. J. Biol. Chem. 273, 7791-7794 24 Protasi, F., et al. (2002) Multiple Regions of RyR1 Mediate Functional and Structural Interactions with [alpha] 1SDihydropyridine Receptors in Skeletal Muscle. Biophys. J. 83, 3230-3244 25 Proenza, C., et al. (2002) Identification of a region of RyR1 that participates in allosteric coupling with the 1S (CaV1. 1) II-III loop. J. Biol. Chem. 277, 6530-6535

26 Altafaj, X., et al. (2005) Maurocalcine and domain A of the II-III loop of the dihydropyridine receptor Cav 1.1 subunit share common binding sites on the skeletal ryanodine receptor. J. Biol. Chem. 280, 4013-4016

27 Casarotto, M.G., et al. (2006) Structural and functional characterization of interactions between the dihydropyridine receptor II-III loop and the ryanodine receptor. Clin. Exp. Pharmacol. Physiol. 33, 1114-1117

28 Peralvarez-Marin, A., et al. (2011) 3D Mapping of the SPRY2 domain of ryanodine receptor 1 by single-particle cryo-EM. PloS ONE 6, e25813

29 Cui, Y., et al. (2009) A dihydropyridine receptor [alpha] 1s loop region critical for skeletal muscle contraction is intrinsically unstructured and binds to a SPRY domain of the type 1 ryanodine receptor. Int. J. Biochem. Cell. Biol. 41, 677-686

30 Cheng, W., et al. (2005) Interaction between the dihydropyridine receptor Ca2+ channel -subunit and ryanodine receptor type 1 strengthens excitation-contraction coupling. Proc. Natl. Acad. Sci. U.S.A. 102, 19225-19230

31 Beam, K.G. and Bannister, R.A. (2010) Looking for answers to EC coupling's persistent questions. J. Gen. Physiol. 136, 7-12

32 Yamazawa, T., et al. (1997) A region of the ryanodine receptor critical for excitation-contraction coupling in skeletal muscle. J. Biol. Chem. 272, 8161-8164

33 Perez, C.F., et al. (2003) Amino acids 1-1,680 of ryanodine receptor type 1 hold critical determinants of skeletal type for excitation-contraction coupling. J. Biol. Chem. 278, 39644-39652

34 Yamazawa, T., et al. (1996) Subtype specificity of the ryanodine receptor for Ca2+ signal amplification in excitationcontraction coupling. EMBO J. 15, 6172-6177

35 Nakai, J., et al. (1998) Two Regions of the Ryanodine Receptor Involved in Coupling withl-Type Ca2+ Channels. J. Biol. Chem. 273, 13403-13406

36 Prosser, B.L., et al. (2011) S100A1 and calmodulin regulation of ryanodine receptor in striated muscle. Cell Calcium 50, 323331 
37 Samsó, M. and Wagenknecht, T. (2002) Apocalmodulin and Ca2+-calmodulin bind to neighboring locations on the ryanodine receptor. J. Biol. Chem. 277, 1349-1353

38 Rodney, G.G., et al. (2005) A calmodulin binding domain of RyR increases activation of spontaneous Ca2+ sparks in frog skeletal muscle. J. Biol. Chem. 280, 11713-11722

39 Menegazzi, P., et al. (1994) Identification and characterization of three calmodulin binding sites of the skeletal muscle ryanodine receptor. Biochemistry 33, 9078-9084

40 Chen, S. and MacLennan, D.H. (1994) Identification of calmodulin-, Ca (2+)-, and ruthenium red-binding domains in the Ca2+ release channel (ryanodine receptor) of rabbit skeletal muscle sarcoplasmic reticulum. J. Biol. Chem. 269, 22698-22704 41 Yamaguchi, N., et al. (2001) Identification of apocalmodulin and Ca2+-calmodulin regulatory domain in skeletal muscle Ca2+ release channel, ryanodine receptor. J. Biol. Chem. 276, 22579-22585

42 Rodney, G.G., et al. (2001) Calcium binding to calmodulin leads to an N-terminal shift in its binding site on the ryanodine receptor. J. Biol. Chem. 276, 2069-2074

43 Zhang, H., et al. (2003) A noncontiguous, intersubunit binding site for calmodulin on the skeletal muscle Ca2+ release channel. J. Biol. Chem. 278, 8348-8355

44 Wright, N.T., et al. (2008) S100A1 and calmodulin compete for the same binding site on ryanodine receptor. J. Biol. Chem.283, 26676-26683

45 Treves, S., et al. (1997) Interaction of S100A1 with the Ca2+ release channel (ryanodine receptor) of skeletal muscle. Biochemistry 36, 11496-11503

46 Prosser, B.L., et al. (2008) S100A1 binds to the calmodulin-binding site of ryanodine receptor and modulates skeletal muscle excitation-contraction coupling. J. Biol. Chem. 283, 5046-5057

47 Prosser, B.L., et al. (2010) S100A1 promotes action potential-initiated calcium release flux and force production in skeletal muscle. Am. J. Physiol. Cell Physiol. 299, C891-C902

48 Yamaguchi, N., et al. (2011) Modulation of sarcoplasmic reticulum Ca2+ release in skeletal muscle expressing ryanodine receptor impaired in regulation by calmodulin and S100A1. Am. J. Physiol. Cell Physiol. 300, C998-C1012

$49 \mathrm{Qi}, \mathrm{Y}$., et al. (1998) FK-binding protein is associated with the ryanodine receptor of skeletal muscle in vertebrate animals. J. Biol. Chem.273, 34813-34819

50 Ahern, G.P., et al. (1997) Subconductance states in single-channel activity of skeletal muscle ryanodine receptors after removal of FKBP12. Biophys. J. 72, 146-162

51 Shou, W., et al. (1998) Cardiac defects and altered ryanodine receptor function in mice lacking FKBP12. Nature 391, 489-492 52 Avila, G., et al. (2003) FKBP12 binding to RyR1 modulates excitation-contraction coupling in mouse skeletal myotubes. J. Biol. Chem. 278, 22600-22608

53 Gaburjakova, M., et al. (2001) FKBP12 binding modulates ryanodine receptor channel gating. J. Biol. Chem. 276, 16931-16935 54 Tang, W., et al. (2004) Altered excitation-contraction coupling with skeletal muscle specific FKBP12 deficiency. FASEB J. 18, 1597-1599

55 Marx, S.O., et al. (1998) Coupled gating between individual skeletal muscle Ca2+ release channels (ryanodine receptors). Science 281, 818-821

56 Wagenknecht, T., et al. (1997) Locations of calmodulin and FK506-binding protein on the three-dimensional architecture of the skeletal muscle ryanodine receptor. J. Biol. Chem. 272, 32463-32471

57 Cornea, R.L., et al. (2010) Mapping the ryanodine receptor FK506-binding protein subunit using fluorescence resonance energy transfer. J. Biol. Chem. 285, 19219-19226

58 Serysheva, I.I., et al. (2008) Subnanometer-resolution electron cryomicroscopy-based domain models for the cytoplasmic region of skeletal muscle RyR channel. Proc. Natl. Acad. Sci. U.S.A. 105, 9610-9615

59 Kobayashi, Y.M., et al. (2000) Localization and characterization of the calsequestrin-binding domain of triadin 1. J. Biol. Chem. 275, 17639-17646

60 Lee, J.M., et al. (2004) Negatively charged amino acids within the intraluminal loop of ryanodine receptor are involved in the interaction with triadin. J. Biol. Chem. 279, 6994-7000

61 Wang, Y., et al. (2009) Altered stored calcium release in skeletal myotubes deficient of triadin and junctin. Cell Calcium 45, 2937

62 Oddoux, S., et al. (2009) Triadin deletion induces impaired skeletal muscle function. J. Biol. Chem.284, 34918-34929

63 Goonasekera, S.A., et al. (2007) Triadin binding to the C-Terminal luminal loop of the ryanodine receptor is important for skeletal muscle excitation-contraction coupling. J. Gen. Physiol. 130, 365-378

64 Wei, L., et al. (2009) Junctin and triadin each activate skeletal ryanodine receptors but junctin alone mediates functional interactions with calsequestrin. Int. J. Biochem. Cell. Biol. 41, 2214-2224

65 MacLennan, D.H. and Wong, P. (1971) Isolation of a calcium-sequestering protein from sarcoplasmic reticulum. Proc. Natl. Acad. Sci. U.S.A. 68, 1231-1235

66 Perez, C.F. (2011) On the footsteps of Triadin and its role in skeletal muscle. World J. Biol. Chem. 2, 177-183

67 Beard, N.A., et al. (2002) Calsequestrin is an inhibitor of skeletal muscle ryanodine receptor calcium release channels. Biophys. J. 82, 310-320

68 Ryan, T., et al. (2011) Identification of novel ryanodine receptor 1 (RyR1) protein interaction with calcium homeostasis endoplasmic reticulum protein (CHERP). J. Biol. Chem. 286, 17060-17068

69 Laplante, J.M., et al. (2000) Cloning of human Ca2+ homoeostasis endoplasmic reticulum protein (CHERP): regulated expression of antisense CDNA depletes CHERP, inhibits intracellular Ca2+ mobilization and decreases cell proliferation. Biochem. J. 348, 189-199

70 Duncan, R.S., et al. (2005) Effects of Vesl/Homer proteins on intracellular signaling. Exp. Biol. Med. 230, 527-535 71 Pouliquin, P. and Dulhunty, A.F. (2009) Homer and the ryanodine receptor. Eur. Biophys. J. 39, 91-102 
$72 \mathrm{Xia}$, R., et al. (2004) Selenium compounds modulate the calcium release channel/ryanodine receptor of rabbit skeletal muscle by oxidizing functional thiols. Biochem. Pharmacol. 67, 2071-2079

73 Jurynec, M.J., et al. (2008) Selenoprotein $\mathrm{N}$ is required for ryanodine receptor calcium release channel activity in human and zebrafish muscle. Proc. Natl. Acad. Sci. U.S.A. 105, 12485-12490

74 Zorzato, F., et al. (2007) Functional effects of mutations identified in patients with multiminicore disease. IUBMB Life 59, 1420

75 Smith, J.S., et al. (1986) Single channel measurements of the calcium release channel from skeletal muscle sarcoplasmic reticulum. Activation by Ca2+ and ATP and modulation by Mg2+. J. Gen. Physiol. 88, 573-588

76 Sitsapesan, R. and Williams, A. (1997) Regulation of current flow through ryanodine receptors by luminal Ca 2+. J. Membr. Biol. 159, 179-185

77 Laver, D.R., et al. (2004) Luminal Ca2+-regulated Mg2+ Inhibition of Skeletal RyRs Reconstituted as Isolated Channels or Coupled Clusters. J. Gen. Physiol. 124, 741-758

78 Laver, D.R. (2007) Ca2+ stores regulate ryanodine receptor Ca2+ release channels via luminal and cytosolic Ca2+ sites. Biophys. J. 92, 3541-3555

79 Diaz-Sylvester, P.L., et al. (2011) Modulation of cardiac ryanodine receptor channels by alkaline earth cations. PLoS ONE 6, e26693

80 Meissner, G. (2002) Regulation of mammalian ryanodine receptors. Front. Biosci. 7, d2072-d2080

81 Treves, S., et al. (1993) Identification of the domain recognized by anti-(ryanodine receptor) antibodies which affect $\mathrm{Ca}(2+)$ induced Ca2+ release. Biochem. J. 291 ( Pt 3), 757-763

82 Chen, S., et al. (1992) Characterization of a Ca2+ binding and regulatory site in the Ca2+ release channel (ryanodine receptor) of rabbit skeletal muscle sarcoplasmic reticulum. J. Biol. Chem. 267, 23318-23326

83 Chen, S., et al. (1993) Antibodies as probes for Ca2+ activation sites in the Ca2+ release channel (ryanodine receptor) of rabbit skeletal muscle sarcoplasmic reticulum. J. Biol. Chem. 268, 13414-13421

84 Chen, S., et al. (1998) Molecular identification of the ryanodine receptor Ca2+ sensor. J. Biol. Chem. 273, 14675-14678

85 Bhat, M.B., et al. (1997) Functional calcium release channel formed by the carboxyl-terminal portion of ryanodine receptor.

Biophys. J. 73, 1329-1336

86 Du, G.G. and MacLennan, D.H. (1999) Ca2+ inactivation sites are located in the COOH-terminal quarter of recombinant rabbit skeletal muscle Ca2+ release channels (ryanodine receptors). J. Biol. Chem. 274, 26120-26126

87 Fessenden, J.D., et al. (2004) Mutational analysis of putative calcium binding motifs within the skeletal ryanodine receptor isoform, RyR1. J. Biol. Chem. 279, 53028-53035

88 Xiong, L., et al. (2006) A Ca2+-binding domain in RyR1 that interacts with the calmodulin binding site and modulates channel activity. Biophys. J. 90, 173-182

89 Laver, D., et al. (1997) Magnesium inhibition of ryanodine-receptor calcium channels: evidence for two independent mechanisms. J. Membr. Biol. 156, 213-229

90 Gillespie, D., et al. (2012) Is ryanodine receptor a calcium or magnesium channel? Roles of $\mathrm{K}(+)$ and $\mathrm{Mg}(2+)$ during $\mathrm{Ca}(2+)$ release. Cell Calcium doi.org 10.1016/j.ceca.2012.02.001

91 Meissner, G., et al. (1986) Kinetics of rapid Ca2+ release by sarcoplasmic reticulum. Effects of Ca2+, Mg2+, and adenine nucleotides. Biochemistry 25, 236-244

92 Dias, J.M., et al. (2006) Insights into the regulation of the ryanodine receptor: differential effects of Mg2+ and Ca2+ on ATP binding. Biochemistry $45,9408-9415$

93 Laver, D., et al. (1997) Reduced inhibitory effect of $\mathrm{Mg2}+$ on ryanodine receptor-Ca2+ release channels in malignant hyperthermia. Biophys. J. 73, 1913-1924

94 Ogunbayo, O.A., et al. (2011) Cyclic adenosine diphosphate ribose activates ryanodine receptors, whereas NAADP activates two-pore domain channels. J. Biol. Chem.286, 9136-9140

95 Zima, A.V., et al. (2003) Differential modulation of cardiac and skeletal muscle ryanodine receptors by NADH. FEBS Lett. 547, 32-36

96 Xia, R., et al. (2003) Skeletal muscle sarcoplasmic reticulum contains a NADH-dependent oxidase that generates superoxide. Am. J. Physiol. Cell Physiol. 285, C215-221

97 Baker, M.L., et al. (2002) The skeletal muscle Ca2+ release channel has an oxidoreductase-like domain. Proc. Natl. Acad. Sci. U.S.A. 99, 12155-12160

98 Bellinger, A.M., et al. (2008) Stressed out: the skeletal muscle ryanodine receptor as a target of stress. J. Clin. Invest. 118, 445453.

99 Witcher, D., et al. (1991) Unique phosphorylation site on the cardiac ryanodine receptor regulates calcium channel activity. J. Biol. Chem. 266, 11144-11152

100 Dulhunty, A.F., et al. (2001) Characteristics of irreversible ATP activation suggest that native skeletal ryanodine receptors can be phosphorylated via an endogenous CaMKII. Biophys. J. 81, 3240-3252

101 Rodriguez, P., et al. (2003) Stoichiometric phosphorylation of cardiac ryanodine receptor on serine 2809 by calmodulindependent kinase II and protein kinase A. J. Biol. Chem. 278, 38593-38600

102 Wehrens, X.H.T., et al. (2004) Ca2+/calmodulin-dependent protein kinase II phosphorylation regulates the cardiac ryanodine receptor. Circ. Res. 94, e61-e70

103 Reiken, S., et al. (2003) PKA phosphorylation activates the calcium release channel (ryanodine receptor) in skeletal muscle. J. Cell Biol. 160, 919-928

104 Hain, J., et al. (1994) Phosphorylation modulates the function of the calcium release channel of sarcoplasmic reticulum from skeletal muscle. Biophys. J. 67, 1823-1833 
105 Sonnleitner, A., et al. (1997) Gating of the skeletal calcium release channel by ATP is inhibited by protein phosphatase 1 but not by Mg2+. Cell Calcium 21, 283-290

106 Marks, A.R., et al. (2002) Regulation of ryanodine receptors via macromolecular complexes: a novel role for leucine/isoleucine zippers. Trends Cardiovasc. Med. 12, 166-170

107 Guerrini, R., et al. (1995) Calmodulin binding sites of the skeletal, cardiac, and brain ryanodine receptor Ca2+ channels: modulation by the catalytic subunit of cAMP-dependent protein kinase? Biochemistry 34, 5120-5129

108 Stange, M., et al. (2003) Characterization of recombinant skeletal muscle (Ser-2843) and cardiac muscle (Ser-2809) ryanodine receptor phosphorylation mutants. J. Biol. Chem. 278, 51693-51702

109 Bellinger, A.M., et al. (2009) Hypernitrosylated ryanodine receptor/calcium release channels are leaky in dystrophic muscle. Nat. Med. 15, 325-330

110 Sun, J., et al. (2001) Classes of thiols that influence the activity of the skeletal muscle calcium release channel. J. Biol. Chem. 276, 15625-15630

111 Zissimopoulos, S., et al. (2007) Redox sensitivity of the ryanodine receptor interaction with FK506-binding protein. J. Biol. Chem. 282, 6976-6983

112 Zissimopoulos, S. and Lai, F. (2006) Redox regulation of the ryanodine receptor/calcium release channel. Biochem. Soc. Trans. 34, 919-921

113 Aracena-Parks, P., et al. (2006) Identification of cysteines involved in S-nitrosylation, S-glutathionylation, and oxidation to disulfides in ryanodine receptor type 1. J. Biol. Chem. 281, 40354-40368

114 Voss, A.A., et al. (2004) Identification of hyperreactive cysteines within ryanodine receptor type 1 by mass spectrometry. J. Biol. Chem. 279, 34514-34520

115 Moore, C.P., et al. (1999) A role for cysteine 3635 of RYR1 in redox modulation and calmodulin binding. J. Biol. Chem. 274, 36831-36834

116 Samsó, M., et al. (2005) Internal structure and visualization of transmembrane domains of the RyR1 calcium release channel by cryo EM. Nat. Struct. Mol. Biol. 12, 539-544

117 Yano, M., et al. (2006) Mechanisms of disease: ryanodine receptor defects in heart failure and fatal arrhythmia. Nat. Clin. Pract. Cardiovasc. Med. 3, 43-52

118 Yamamoto, T., et al. (2000) Postulated role of interdomain interaction within the ryanodine receptor in Ca2+ channel regulation. J. Biol. Chem. 275, 11618-11625

119 Hayek, S.M., et al. (2000) Characterization of a calcium-regulation domain of the skeletal-muscle ryanodine receptor. Biochem. J. 351, 57-65

120 Dulhunty, A., et al. (2006) Novel regulators of RyR Ca 2+ release channels: insight into molecular changes in geneticallylinked myopathies. J. Muscle Res. Cell Motil. 27, 351-365

121 Hamada, T., et al. (2007) Peptide probe study of the role of interaction between the cytoplasmic and transmembrane domains of the ryanodine receptor in the channel regulation mechanism. Biochemistry 46, 4272-4279

122 Monnier, N., et al. (2008) Null mutations causing depletion of the type 1 ryanodine receptor (RYR1) are commonly associated with recessive structural congenital myopathies with cores. Hum. Mutat. 29, 670-678

123 Duarte, S.T., et al. (2011) Dominant and recessive RYR1 mutations in adults with core lesions and mild muscle symptoms. Muscle Nerve 44, 102-108

124 Zhou, H., et al. (2010) Multi-minicore disease and atypical periodic paralysis associated with novel mutations in the skeletal muscle ryanodine receptor (RYR1) gene. Neuromusc. Disord. 20, 166-173

125 Bevilacqua, J.A., et al. (2011) Recessive RYR1 mutations cause unusual congenital myopathy with prominent nuclear internalization and large areas of myofibrillar disorganization. Neuropathol. Appl. Neurobiol. 37, 271-284 


\section{TEXT BOXES}

Box 1. RyR1-related muscle disorders.

Malignant hyperthermia ( $\mathbf{M H})$ is a potentially fatal pharmacogenetic disorder in which a hypermetabolic state is evoked by volatile anaesthetics or depolarizing muscle agents. Symptoms include hypercapnia, metabolic acidosis, tachycardia, generalized muscle rigidity, rhabdomyolysis, and hyperthermia. Most MH-susceptible individuals have normal muscle function so long as triggering agents are avoided but some individuals with congenital myopathies because of $R Y R 1$ mutations may be at risk of developing an $\mathrm{MH}$ reaction. Dantrolene, which acts on RyR1, is currently the only available treatment. Dominant $R Y R 1$ mutations are the leading cause of $\mathrm{MH}$.

Congenital myopathies are uncommon muscle disorders that usually present at birth or during infancy with generalized muscle weakness and low muscle tone. There are many forms of congenital myopathy, each defined by a specific pattern of histologic abnormalities. The clinical severity varies. Most individuals with congenital myopathies follow a stable clinical course and current medical treatment is based on supportive care. Patients may develop respiratory involvement, joint contractures, distinctive weakness of eye movements (ophthalmoplegia), scoliosis, or difficulty swallowing (dysphagia). Mutations in RYR1 are an important cause of the following congenital myopathies.

- The core myopathies are characterized by regions devoid of mitochondria in muscle fibers that appear as 'cores' on oxidative stains. In central core disease (CCD), cores are large and extend longitudinally. In multi-minicore disease $(\mathbf{M m D})$ the cores are short and vary in size and location.

- Centronuclear myopathy (CNM) is characterized by the presence of numerous internally located nuclei within muscle fibers.

- Congenital fiber type disproportion (CFTD) is characterized by a marked consistent difference in size between type 1 fibers (which are small) and type 2 fibers (which are large), when there are no other histological abnormalities. 


\section{FIGURE LEGENDS}

2

3 Figure 1. Protein/ion binding domains distributed across the RyR1 protein sequence.

4

5 Figure 2. Proposed architecture of RyR1 based on cryo-EM at $10 \AA ̊$ resolution. Adapted from [116].

6

7 Figure 3. Interdomain interaction within RyR1. The N-terminal and central domains interact with

8 one another to stabilize the closed configuration of the channel. When this interaction is disrupted

9 and "unzipped," either by means of a competing synthetic domain peptide, pathogenic mutation,

10 or physiologic activation, the channel becomes destabilized and allows the passage of calcium ions

11 through the pore. aa = amino acids. Adapted from [117].

12

13 
1 Figure 1:

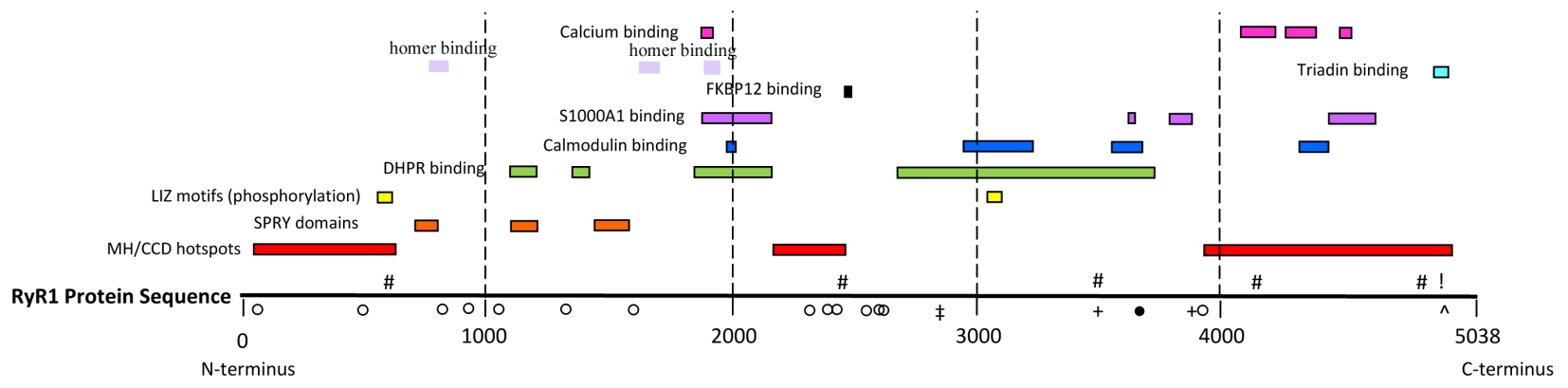

\# Interdomain Interactions

+ Alternatively Spliced Regions

! Selectivity filter

¥ Phosphorylation site

- Redox site-possible

- Redox site-probable

$\wedge$ Critical pore residue

\section{Figure 2}




\section{$1 \quad$ Figure 3}

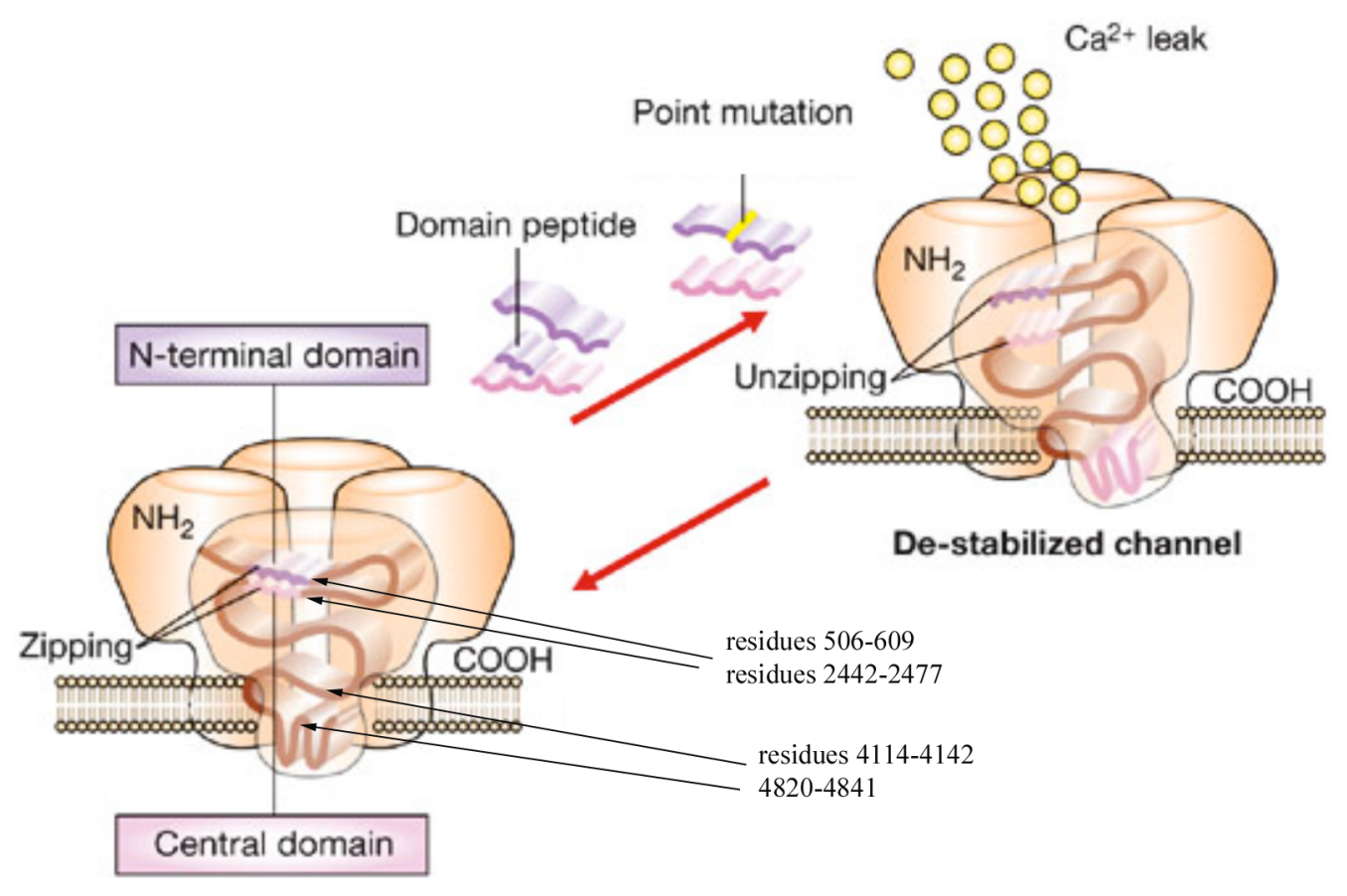

2 
1 Table 1. Human RyR1 domains and effects on channel function arranged by amino acid range.

\begin{tabular}{|c|c|c|c|c|}
\hline $\begin{array}{l}\text { Amino Acid } \\
\text { Range }\end{array}$ & Domain & $\begin{array}{c}\text { Function/Effect on } \\
\text { RyR1 }\end{array}$ & $\begin{array}{l}\text { Supporting } \\
\text { Evidence }\end{array}$ & Refs \\
\hline $35-614$ & $\begin{array}{l}\mathrm{MH} / \mathrm{CCD} \text { hotspot } \\
\text { region } 1\end{array}$ & -- & $\begin{array}{l}\text { Human genetic } \\
\text { studies }\end{array}$ & [2] \\
\hline $553-602$ & $\begin{array}{l}\text { Leucine/Isoleucine } \\
\text { zipper (LIZ) motifs }\end{array}$ & $\begin{array}{l}\text { Binds to and localizes } \\
\text { kinases/phosphatases } \\
\text { on RyR1, } \\
\text { phosphorylation } \\
\text { activates RyR1 }\end{array}$ & $\begin{array}{l}\text { Experimental } \\
\text { studies }\end{array}$ & [106] \\
\hline $589-608$ & $\begin{array}{l}\text { Interdomain } \\
\text { interactions }\end{array}$ & $\begin{array}{l}\text { Stabilizes closed } \\
\text { conformation, } \\
\text { inactivates RyR1 }\end{array}$ & $\begin{array}{l}\text { Experimental } \\
\text { studies }\end{array}$ & [118] \\
\hline $659-797$ & SPRY1 domain & $\begin{array}{l}\text { Protein-protein } \\
\text { interaction motif, } \\
\text { exact effect on RyR1 } \\
\text { unknown }\end{array}$ & In silico analysis & -- \\
\hline 801 FLPPP 805 & Binding to homer & $\begin{array}{l}\text { Likely mediates } \\
\text { protein-protein } \\
\text { interactions, may } \\
\text { activate RyR1 }\end{array}$ & In silico analysis & {$[71]$} \\
\hline $1084-1207$ & SPRY2 domain & $\begin{array}{l}\text { Binding to DHPR } \alpha_{1 \mathrm{~s}} \text { II- } \\
\text { III loop, activates RyR1 }\end{array}$ & $\begin{array}{l}\text { In silico analysis, } \\
\text { experimental } \\
\text { studies }\end{array}$ & {$[27,29]$} \\
\hline $1272-1455$ & $\begin{array}{l}\text { Divergent region } 2 \\
\text { (D2) }\end{array}$ & $\begin{array}{l}\text { Binding to DHPR and } \\
\text { responsible for } \\
\text { formation of DHPR } \\
\text { tetrads }\end{array}$ & $\begin{array}{l}\text { Experimental } \\
\text { studies }\end{array}$ & {$[21,32,33]$} \\
\hline $1430-1570$ & SPRY3 domain & $\begin{array}{l}\text { Protein-protein } \\
\text { interaction motif, } \\
\text { exact effect on RyR1 } \\
\text { unknown }\end{array}$ & In silico analysis & -- \\
\hline $\begin{array}{l}1773 \text { PPHHF } \\
1777\end{array}$ & Binding to homer & $\begin{array}{l}\text { Likely mediates } \\
\text { protein-protein } \\
\text { interactions, may } \\
\text { activate RyR1 }\end{array}$ & In silico analysis & [71] \\
\hline $1837-2168$ & Binding to DHPR & Activates RyR1 & $\begin{array}{l}\text { Experimental } \\
\text { studies }\end{array}$ & {$[25,35]$} \\
\hline $1861-2155$ & Binding to S100A1 & Activates RyR1 & $\begin{array}{l}\text { Experimental } \\
\text { studies }\end{array}$ & [45] \\
\hline $1872-1922$ & $\begin{array}{l}\text { Low affinity } \mathrm{Ca}^{2+} \\
\text { inactivation site }\end{array}$ & Inactivates RyR1 & $\begin{array}{l}\text { Experimental } \\
\text { studies }\end{array}$ & [119] \\
\hline $1975-1999$ & $\begin{array}{l}\text { Binding to } \\
\text { calmodulin }\end{array}$ & $\begin{array}{l}\text { Effect depends on } \\
\text { which form is bound } \\
\text { (apoCaM is a partial } \\
\text { agonist vs. CaCaM is }\end{array}$ & $\begin{array}{l}\text { Experimental } \\
\text { studies }\end{array}$ & [43] \\
\hline
\end{tabular}




\begin{tabular}{|c|c|c|c|c|}
\hline & & an antagonist of RyR1) & & \\
\hline $\begin{array}{l}1998 \text { FRSPP } \\
2002\end{array}$ & Binding to homer & $\begin{array}{l}\text { Likely mediates } \\
\text { protein-protein } \\
\text { interactions, may } \\
\text { activate RyR1 }\end{array}$ & In silico analysis & [71] \\
\hline $2163-2458$ & $\begin{array}{l}\mathrm{MH} / \mathrm{CCD} \text { hotspot } \\
\text { region } 2\end{array}$ & -- & $\begin{array}{l}\text { Human genetic } \\
\text { studies }\end{array}$ & -- \\
\hline $2442-2477$ & $\begin{array}{l}\text { Interdomain } \\
\text { interactions }\end{array}$ & $\begin{array}{l}\text { Stabilizes closed } \\
\text { conformation, } \\
\text { inactivates RyR1 }\end{array}$ & $\begin{array}{l}\text { Experimental } \\
\text { studies }\end{array}$ & [118] \\
\hline $2458-2468$ & Binding to FKBP12 & $\begin{array}{l}\text { Stabilizes closed } \\
\text { conformation, } \\
\text { inactivates RyR1 }\end{array}$ & $\begin{array}{l}\text { Experimental } \\
\text { studies }\end{array}$ & {$[52,53,58]$} \\
\hline $2659-3720$ & Binding to DHPR & Activates RyR1 & $\begin{array}{l}\text { Experimental } \\
\text { studies }\end{array}$ & {$[25,35]$} \\
\hline $2843 S$ & Phosphorylation site & Likely activates RyR1 & $\begin{array}{l}\text { Experimental } \\
\text { studies }\end{array}$ & [103] \\
\hline $2937-3225$ & Binding to apoCaM & $\begin{array}{l}\text { Weak partial agonist, } \\
\text { activates RyR1 }\end{array}$ & $\begin{array}{l}\text { Experimental } \\
\text { studies }\end{array}$ & [39] \\
\hline $3039-3075$ & $\begin{array}{l}\text { Leucine/Isoleucine } \\
\text { zipper (LIZ) motifs }\end{array}$ & $\begin{array}{l}\text { Binds to and localizes } \\
\text { kinases/phosphatases } \\
\text { on RyR1, } \\
\text { phosphorylation } \\
\text { activates RyR1 }\end{array}$ & $\begin{array}{l}\text { Experimental } \\
\text { studies }\end{array}$ & [106] \\
\hline $3471-3500$ & $\begin{array}{l}\text { ASI region + basic } \\
\text { sequence }\end{array}$ & $\begin{array}{l}\text { Possible interdomain } \\
\text { interaction which } \\
\text { stabilizes closed } \\
\text { conformation }\end{array}$ & $\begin{array}{l}\text { Experimental } \\
\text { studies }\end{array}$ & {$[16,120]$} \\
\hline $3481-3485$ & ASI region & See above & $\begin{array}{l}\text { Experimental } \\
\text { studies }\end{array}$ & {$[16,30,120]$} \\
\hline $3495-3502$ & $\begin{array}{l}\text { Basic sequence } \\
\text { upstream from ASI } \\
\text { region }\end{array}$ & $\begin{array}{l}\text { Possible binding to } \\
\text { DHPR } \beta_{1 a} \text { subunit, } \\
\text { may stabilize } \\
\text { interaction between } \\
\text { DHPR and RyR1 }\end{array}$ & $\begin{array}{l}\text { Experimental } \\
\text { studies }\end{array}$ & [30] \\
\hline $3546-3655$ & Binding to apoCaM & $\begin{array}{l}\text { Weak partial agonist, } \\
\text { activates RyR1 }\end{array}$ & $\begin{array}{l}\text { Experimental } \\
\text { studies }\end{array}$ & [39-41] \\
\hline $3553-3662$ & Binding to $\mathrm{CaCaM}$ & $\begin{array}{l}\text { Antagonist, } \\
\text { inactivates RyR1 }\end{array}$ & $\begin{array}{l}\text { Experimental } \\
\text { studies }\end{array}$ & [39-41] \\
\hline $3614-3643$ & $\begin{array}{l}\text { Binding to } \\
\text { calmodulin (apoCaM } \\
\text { and CaCaM) }\end{array}$ & $\begin{array}{l}\text { Effect depends on } \\
\text { which form is bound } \\
\text { (apoCaM is a partial } \\
\text { agonist vs. CaCaM is } \\
\text { an antagonist of RyR1) }\end{array}$ & $\begin{array}{l}\text { Experimental } \\
\text { studies }\end{array}$ & {$[39,40]$} \\
\hline $3616-3627$ & Binding to S100A1 & Activates RyR1 & $\begin{array}{l}\text { Experimental } \\
\text { studies }\end{array}$ & {$[44]$} \\
\hline $3635 C$ & Redox modulation & Likely activates RyR1 & Experimental & {$[113,114]$} \\
\hline
\end{tabular}




\begin{tabular}{|c|c|c|c|c|}
\hline & site & & studies & \\
\hline $3773-3873$ & Binding to S100A1 & Activates RyR1 & $\begin{array}{l}\text { Experimental } \\
\text { studies }\end{array}$ & {$[45]$} \\
\hline $3865-3870$ & ASII region & Unknown & $\begin{array}{l}\text { Experimental } \\
\text { studies }\end{array}$ & {$[16]$} \\
\hline $3916-4943$ & $\begin{array}{l}\mathrm{MH} / \mathrm{CCD} \text { hotspot } \\
\text { region } 3\end{array}$ & -- & $\begin{array}{l}\text { Human genetic } \\
\text { studies }\end{array}$ & -- \\
\hline $4063-4209$ & $\begin{array}{l}\text { Broad region } \\
\text { containing } \mathrm{Ca}^{2+} \\
\text { binding sites } \\
\end{array}$ & Unknown(?) & $\begin{array}{l}\text { Experimental } \\
\text { studies }\end{array}$ & [88] \\
\hline $4080-4091$ & $\begin{array}{l}\text { Low affinity } \mathrm{Ca}^{2+} \\
\text { inactivation site }\end{array}$ & Inactivates RyR1 & $\begin{array}{l}\text { Experimental } \\
\text { studies }\end{array}$ & [87] \\
\hline $4113-4141$ & $\begin{array}{l}\text { Interdomain } \\
\text { interactions }\end{array}$ & $\begin{array}{l}\text { Stabilizes closed } \\
\text { conformation, } \\
\text { inactivates RyR1 }\end{array}$ & $\begin{array}{l}\text { Experimental } \\
\text { studies }\end{array}$ & [121] \\
\hline $4245-4378$ & $\begin{array}{l}\text { High affinity } \mathrm{Ca}^{2+} \\
\text { activation site }\end{array}$ & Activates RyR1 & $\begin{array}{l}\text { Experimental } \\
\text { studies }\end{array}$ & [82] \\
\hline $4303-4431$ & Binding to apoCaM & $\begin{array}{l}\text { Weak partial agonist, } \\
\text { activates RyR1 }\end{array}$ & $\begin{array}{l}\text { Experimental } \\
\text { studies }\end{array}$ & {$[40,41]$} \\
\hline $4426-4622$ & Binding to S100A1 & Activates RyR1 & $\begin{array}{l}\text { Experimental } \\
\text { studies }\end{array}$ & [45] \\
\hline $4490-4502$ & $\begin{array}{l}\text { High affinity } \mathrm{Ca}^{2+} \\
\text { activation site }\end{array}$ & Activates RyR1 & $\begin{array}{l}\text { Experimental } \\
\text { studies }\end{array}$ & [83] \\
\hline $4821-4842$ & $\begin{array}{l}\text { Interdomain } \\
\text { interactions }\end{array}$ & $\begin{array}{l}\text { Stabilizes closed } \\
\text { conformation, } \\
\text { inactivates RyR1 }\end{array}$ & $\begin{array}{l}\text { Experimental } \\
\text { studies }\end{array}$ & [121] \\
\hline $4861-4918$ & Binding to triadin & Activates RyR1 & $\begin{array}{l}\text { Experimental } \\
\text { studies }\end{array}$ & [60] \\
\hline $\begin{array}{l}4895 \text { GGGIGD } \\
4900\end{array}$ & Selectivity filter & $\begin{array}{l}\text { Channel conductance } \\
\text { and cation selectivity }\end{array}$ & $\begin{array}{l}\text { Experimental and } \\
\text { molecular } \\
\text { dynamics } \\
\text { simulations } \\
\text { studies }\end{array}$ & {$[6,7]$} \\
\hline
\end{tabular}

1 Abbreviations: $\mathrm{MH}$, malignant hyperthermia; $\mathrm{CCD}$, central core disease; DHPR, dihydropyridine

2 receptor; apoCaM, calmodulin with unbound calcium; CaCaM, calmodulin with bound calcium; AS,

3 alternatively spliced. 
1 Table 2. RyR1 domains and effects on channel function arranged by binding protein/ion.

\begin{tabular}{|c|c|c|c|c|}
\hline $\begin{array}{l}\text { Binding } \\
\text { proteins/ } \\
\text { intrinsic } \\
\text { regions/ions }\end{array}$ & $\begin{array}{l}\text { Amino acid range } H \\
\text { (human)/R (rabbit) } \\
\text { cDNA sequence }\end{array}$ & Domain & Functional effect on RyR1 & Refs \\
\hline $\begin{array}{l}\text { Interdomain } \\
\text { interaction }\end{array}$ & $\begin{array}{l}\text { H } 589-608 \\
\text { H } 2442-2477 \\
\text { H } 4113-4141 ; 4821- \\
4842\end{array}$ & $\begin{array}{l}\mathrm{MH} / \mathrm{CCD} \text { domain } 1 \\
\mathrm{MH} / \mathrm{CCD} \text { domain } 2 \\
\mathrm{MH} / \mathrm{CCD} \text { domain } 3\end{array}$ & Stabilize closed conformation & {$[121]$} \\
\hline $\begin{array}{l}\text { Alternative } \\
\text { splice variants }\end{array}$ & 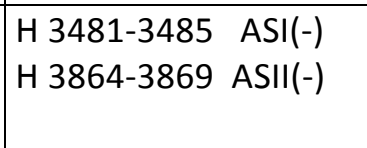 & - & $\begin{array}{l}\text { Possible interdomain } \\
\text { interaction stabilizing closed } \\
\text { conformation }\end{array}$ & $\begin{array}{l}{[16,} \\
120]\end{array}$ \\
\hline SPRY & $\begin{array}{ll}\text { H } 659-797 & \text { SPRY1 } \\
\text { H 1084-1207 } & \text { SPRY2 } \\
\text { H 1430-1570 } & \text { SPRY3 }\end{array}$ & - & \begin{tabular}{|l|} 
Protein-protein interacting \\
domain; SPRY2 identified as \\
binding DHPR $\alpha_{1 s}$ II-III loop
\end{tabular} & \\
\hline $\begin{array}{l}\text { DHPR } \alpha_{1 s} \text { II-III } \\
\text { loop }\end{array}$ & $\begin{array}{l}\text { H } 1076-1112 \\
\text { R 1837-2168 } \\
\text { R 2642-3770 } \\
\text { R } 3351-3507\end{array}$ & $\begin{array}{l}\text { SPRY2 domain } \\
\text { MH/CCD domain } 2\end{array}$ & $\begin{array}{l}\text { Orthograde signaling } \\
\text { Contribute to skeletal EC } \\
\text { coupling (orthograde and } \\
\text { retrograde) }\end{array}$ & $\begin{array}{l}{[21,23,} \\
25,26, \\
33]\end{array}$ \\
\hline DHPR ß1 & $\begin{array}{l}\text { H 3495-3502 } \\
\text { R 3201-3661 }\end{array}$ & ASI (-) & $\begin{array}{l}\text { Strengthens effect of } \\
\text { interaction via + ve charges }\end{array}$ & [30] \\
\hline $\begin{array}{l}\text { Tetrad } \\
\text { formation }\end{array}$ & H 1272-1455 & & $\begin{array}{l}\text { Tetrad formation enhanced } \\
\text { but sequence not sufficient }\end{array}$ & [21] \\
\hline FKBP12 & H 2458-2468 & $\mathrm{MH} / \mathrm{CCD}$ domain 2 & Stabilizes closed state & $\begin{array}{l}{[52,53,} \\
58]\end{array}$ \\
\hline Calmodulin & $\begin{array}{l}\text { H 2937-3225 ApoCaM } \\
\text { H 3553-3662 CaCaM } \\
\text { H 3614-3663 Apo and } \\
\text { CaCaM } \\
\text { H 4303-4431 CaCaM }\end{array}$ & $\mathrm{MH} / \mathrm{CCD}$ domain 3 & & [41] \\
\hline S100A1 & $\begin{array}{l}\text { H } 1861-2155 \\
\text { H } 3616-3627 \\
\text { H } 3773-3873 \\
\text { H } 4426-4622 \\
\end{array}$ & Overlaps with CaM binding & $\begin{array}{l}\text { Activates RyR1 } \\
\text { Activates RyR1 } \\
\text { Activates RyR1 } \\
\text { Activates RyR1 }\end{array}$ & {$[45,46]$} \\
\hline Triadin & H 4861-4918 & MH/CCD domain 3 & Rapid $\mathrm{Ca}^{2+}$ release & {$[60]$} \\
\hline $\begin{array}{l}\text { Kinases/ } \\
\text { phosphotases }\end{array}$ & $\begin{array}{l}\text { H 552-602 PPI } \\
\text { H 3039-3075 PKA }\end{array}$ & $\begin{array}{l}\text { Leu/Ile zipper (LIZ) } \\
\text { motifs } \\
\text { Leu/lle zipper (LIZ) } \\
\text { motifs }\end{array}$ & $\begin{array}{l}\text { Phosphorylation activates } \\
\text { RyR1 }\end{array}$ & [106] \\
\hline Homer & \begin{tabular}{|l|}
$H$ \\
H $1701-805$ \\
H $1998-1777$ \\
\end{tabular} & & Enhances RyR1 function & {$[71]$} \\
\hline $\begin{array}{l}\text { Redox } \\
\text { sensitive Cys }\end{array}$ & H Cys3635 & & Activates RyR1 & \begin{tabular}{|l}
{$[111$,} \\
113 \\
$114]$
\end{tabular} \\
\hline $\begin{array}{l}\text { Phosphorylati } \\
\text { on site }\end{array}$ & H Ser2843 & - & Channel opening & [103] \\
\hline
\end{tabular}




\begin{tabular}{|l|l|l|l|l|}
\hline $\mathrm{Ca}^{2+}$ binding & H $1872-1922$ & & Low affinity, $\mathrm{Ca}^{2+}$ inactivation & {$[82,83$,} \\
domain & H 4080-4091 & MH/CCD domain 3 & Low affinity $\mathrm{Ca}^{2+}$ inactivation & $87,119]$ \\
& H 4245-4378 & MH/CCD domain 3 & Ca ${ }^{2+}$ binding & \\
& H 4490-4502 & MH/CCD domain 3 & High affinity Ca ${ }^{2+}$ activation & \\
\hline
\end{tabular}

1 Abbreviations: $\mathrm{H}$, human; $\mathrm{R}$, rabbit; $\mathrm{MH}$, malignant hyperthermia; $\mathrm{CCD}$, central core disease; $\mathrm{AS}$, 2 alternatively sliced; DHPR, dihydropyridine receptor.

3

4 
1 Table 3. Recessive RYR1 mutations and neuromuscular diseases. Genetic RYR1 mutations and the

2 corresponding possible protein/ion binding domains affected are listed, along with a brief

3 description of clinical phenotypes.

\begin{tabular}{|c|c|c|c|c|c|c|c|}
\hline $\begin{array}{l}\text { RYR1 Mutation } \\
\text { L }\end{array}$ & RYR1 Mutation 2 & $\begin{array}{l}\text { RyR1 alleles } \\
\text { expressed in } \\
\text { muscle }\end{array}$ & $\begin{array}{l}\text { Predicted } \\
\text { maximum } \\
\text { level of } \\
\text { RyR1 } \\
\text { expressed } \\
*\end{array}$ & $\begin{array}{l}\text { Observed } \\
\text { level of } \\
\text { RyR1 } \\
\text { expressed }\end{array}$ & $\begin{array}{l}\text { Histological } \\
\text { diagnosis }\end{array}$ & $\begin{array}{l}\text { RyR1 domain } \\
\text { implicated in } \\
\text { disease } \\
\text { pathogenesis }\end{array}$ & Refs \\
\hline $\begin{array}{l}. .212 C>A \\
0 . S 71 Y\end{array}$ & $\begin{array}{l}\text { c. } 6847 \mathrm{~A}>\mathrm{C} \\
\text { p.N2283H }\end{array}$ & $\begin{array}{l}\text { S71Y \& } \\
\text { N2283H }\end{array}$ & $100 \%$ & Normal & Cores & & [2] \\
\hline $\begin{array}{l}.325 C>T \\
0 . R 109 W\end{array}$ & Monoallelic & R109W & $50 \%$ & Reduced & Cores & & [2] \\
\hline $\begin{array}{l}.1205 \mathrm{~T}>\mathrm{C} \\
\mathrm{J.M} 402 \mathrm{~L}\end{array}$ & $\begin{array}{l}\text { c. } 5333 C>A \\
\text { p.S1778X }\end{array}$ & M402L & $50 \%$ & Reduced & CFTD & & [3] \\
\hline $\begin{array}{l}.1205 T>C \\
\text { J.M402T }\end{array}$ & Monoallelic & M402T & $50 \%$ & Reduced & Some cores & & [2] \\
\hline $\begin{array}{l}. .4024 A>G \\
0 . S 1342 G\end{array}$ & $\begin{array}{l}\text { c. } 8360 C>G \\
\text { p.T2787S }\end{array}$ & $\begin{array}{l}\text { S1342G \& } \\
\text { T2787S }\end{array}$ & $100 \%$ & - & CNM & $\begin{array}{l}\text { Tetrad formation } \\
(1341-1402)+ \\
\text { DHPR Cav }_{1.1} \\
(2642-3770)\end{array}$ & [4] \\
\hline $\begin{array}{l}.5110 \mathrm{G}>\mathrm{A} \\
. \mathrm{G} 1704 \mathrm{~S}\end{array}$ & $\begin{array}{l}\text { c.12801_12802ins } \\
\text { p.A4268RfsX7 }\end{array}$ & G1704S & $50 \%$ & $\begin{array}{l}\text { Slightly } \\
\text { reduced }\end{array}$ & Cores & & [122] \\
\hline $\begin{array}{l}.6104 \mathrm{~A}>\mathrm{T} \\
\mathrm{J.H2035 \textrm {L }}\end{array}$ & $\begin{array}{l}\text { c.738T >G } \\
\text { p.Y246X }\end{array}$ & H2035L & $50 \%$ & - & CFTD & $\begin{array}{l}\text { S100A1 (1861- } \\
\text { 2155) }\end{array}$ & [3] \\
\hline $\begin{array}{l}2.6612 C>G \\
. . H 2204 G\end{array}$ & $\begin{array}{l}\text { c. } 14228 G>A \\
\text { p.G4743D }\end{array}$ & $\begin{array}{l}\text { H2204G \& } \\
\text { G4743D }\end{array}$ & $100 \%$ & - & $\begin{array}{l}\text { MmD/MHS, } \\
\text { fiber type } 1 \\
\text { predominance }\end{array}$ & $\begin{array}{l}\text { High affinity } \mathrm{Ca}^{2+} \\
\text { binding (4490- } \\
4502)\end{array}$ & [123] \\
\hline $\begin{array}{l}. .7268 \mathrm{~T}>\mathrm{A} \\
\text { J.M2423K }\end{array}$ & Monoallelic & M2423K & $50 \%$ & - & Cores & & [2] \\
\hline $\begin{array}{l}.7268 \mathrm{~T}>\mathrm{A} \\
\text { J.M2423K }\end{array}$ & $\begin{array}{l}\text { c.34delT; c.37C>G } \\
\text { Stop +p.L13V }\end{array}$ & M2423K & $50 \%$ & $\begin{array}{l}\text { Slightly } \\
\text { reduced }\end{array}$ & Cores & & [122] \\
\hline $\begin{array}{l}.7304 G>T \\
0 . R 2435 \mathrm{~L}\end{array}$ & $\begin{array}{l}\text { c.7304G }>\mathrm{T} \\
\text { p.R2435L }\end{array}$ & R2435L & $50 \%$ & Normal & Cores & & [2] \\
\hline $\begin{array}{l}. .6721 \mathrm{C}>\mathrm{T} \\
. \mathrm{R} 2241 \mathrm{X}+ \\
.2122 \mathrm{G}>\mathrm{A} \\
. . \mathrm{D} 708 \mathrm{~N} \\
\end{array}$ & $\begin{array}{l}\text { c. } 8816 \mathrm{G}>\mathrm{A} \\
\text { p.R2939K }\end{array}$ & R2939K & $50 \%$ & Reduced & $\mathrm{MmD}$ & CaM (2937-3225) & [124] \\
\hline $\begin{array}{l}.9247 \mathrm{~T}>\mathrm{C} \\
\text { о.M3081T }\end{array}$ & $\begin{array}{l}\text { c.5726_27 } 2 \text { AG } \\
\text { p.E1909GfsX39 }\end{array}$ & M3081T & $50 \%$ & - & CNM & \begin{tabular}{|l|} 
DHPR Cav \\
(Rabbit $2642-$ \\
$3770)$ \\
\end{tabular} & [4] \\
\hline $\begin{array}{l}2.9413 \mathrm{C}>\mathrm{T} \\
\text { ग.P3138L }\end{array}$ & $\begin{array}{l}\text { c. } 11314 C>T \\
\text { p.R3772W }\end{array}$ & $\begin{array}{l}\text { P3138L \& } \\
\text { R3772W }\end{array}$ & $100 \%$ & - & & \begin{tabular}{|l} 
CaM (2937-3225) \\
+ \\
S100A1? (3773- \\
$3873)$ \\
\end{tabular} & [125] \\
\hline $\begin{array}{l}. .9605 C>T \\
\text { ग.P3202L }\end{array}$ & $\begin{array}{l}\text { c.10561G>T } \\
\text { p.G3521C }\end{array}$ & $\begin{array}{l}\text { P3202L \& } \\
\text { G3521C }\end{array}$ & $100 \%$ & - & & $\begin{array}{l}\text { CaM }(2937-3225) \\
+ \\
\text { DHPR retrograde } \\
(2659-3720)\end{array}$ & [125] \\
\hline
\end{tabular}




\begin{tabular}{|c|c|c|c|c|c|c|c|}
\hline $\begin{array}{l}=.9605 \mathrm{C}>\mathrm{T} \\
\text { J.P3202L }\end{array}$ & $\begin{array}{l}\text { c.12536G>A } \\
\text { p.R4179H }\end{array}$ & $\begin{array}{l}\text { P3202L \& } \\
\text { R4179H }\end{array}$ & $100 \%$ & - & & $\begin{array}{l}\text { CaM }(2937-3225) \\
+ \\
\text { DHPR retrograde } \\
(2659-3720)\end{array}$ & [125] \\
\hline $\begin{array}{l}. .9978 \mathrm{C}>\mathrm{A} \\
\text { o.N3326K }\end{array}$ & $\begin{array}{l}\text { c.9000+1G>T } \\
\text { exon } 95 \text { skipped }\end{array}$ & N3326K & $50 \%$ & Reduced & CFTD & \begin{tabular}{|l} 
DHPR Cav \\
$(2642-3770)$ \\
\end{tabular} & [3] \\
\hline $\begin{array}{l}=.10097 \mathrm{G}>\mathrm{A} \\
\text { ग.R3366H }\end{array}$ & $\begin{array}{l}\text { c.11798G } \\
\text { p.Y3933C }\end{array}$ & $\begin{array}{l}\text { R3366H \& } \\
\text { Y3933C }\end{array}$ & $100 \%$ & - & $\begin{array}{l}\text { MmD/rhabdo, } \\
\text { fiber type } 1 \\
\text { predominance }\end{array}$ & \begin{tabular}{|l} 
DHPR Cav $_{1.1}$ \\
$(2642-3770)$
\end{tabular} & [123] \\
\hline $\begin{array}{l}. .10204 \mathrm{~T}>\mathrm{G} \\
. . \mathrm{C} 3402 \mathrm{G}\end{array}$ & $\begin{array}{l}\text { c.13480G >T } \\
\text { p.Glu4494X }\end{array}$ & C3402G & $50 \%$ & - & CFTD & \begin{tabular}{|l} 
DHPRB1(3201- \\
3661)
\end{tabular} & [3] \\
\hline $\begin{array}{l}. .10343 \mathrm{C}>\mathrm{T} \\
\mathrm{J} . \mathrm{S} 3448 \mathrm{~F}\end{array}$ & c.14365-2AT+ & S3448F & $50 \%$ & - & $\mathrm{MmD}$ & $\begin{array}{l}\text { DHPR Cav }_{1.1} \\
\text { (Rabbit 3351- } \\
3507) \\
\end{array}$ & [2] \\
\hline $\begin{array}{l}.10579 G>A \\
\text { ग.P3527S }\end{array}$ & $\begin{array}{l}\text { c.10579G >A } \\
\text { p.P3527S }\end{array}$ & P3527S & $50 \%$ & - & $\mathrm{CCD} / \mathrm{MmD}$ & $\begin{array}{l}\text { CaM? } \\
(2937-3225)\end{array}$ & [2] \\
\hline $\begin{array}{l}=.10616 \mathrm{G}>\mathrm{A} \\
\text { ग.R3539H }\end{array}$ & $\begin{array}{l}\text { c. } 14804-1 G>T \\
\text { p.G4935.T4957>D } \\
\text { fsX11 }\end{array}$ & $\mathrm{R} 3539 \mathrm{H}$ & $50 \%$ & Reduced & Cores & $\begin{array}{l}\text { DHPR retrograde } \\
(2659-3720)\end{array}$ & [122] \\
\hline $\begin{array}{l}=.11315 G>A \\
J . R 3772 E\end{array}$ & $\begin{array}{l}\text { c.5938 } \Delta \text { C } \\
\text { p.Leu1980SerfsX1 }\end{array}$ & R3772E & $50 \%$ & Reduced & Cores & $\begin{array}{l}\text { S100A1? (3773- } \\
\text { 3873) }\end{array}$ & [122] \\
\hline $\begin{array}{l}=.11315 G>A \\
0 . R 3772 Q\end{array}$ & \begin{tabular}{|l|} 
c. $11315 G>A$ \\
p.R3772Q
\end{tabular} & R3772Q & $50 \%$ & - & & $\begin{array}{l}\text { S100A1? (3773- } \\
\text { 3873) }\end{array}$ & [2] \\
\hline $\begin{array}{l}. .11941 \mathrm{C}>\mathrm{T} \\
\text { o.H3981Y }\end{array}$ & 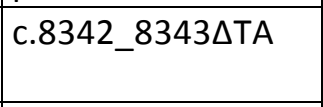 & H3981Y & $50 \%$ & - & CNM & None known & [4] \\
\hline $\begin{array}{l}. .12986 C>A \\
\text { ग.A4329D }\end{array}$ & Monoallelic & A4329D & $50 \%$ & Reduced & Cores & $\mathrm{Ca}^{2+}(4245-4378)$ & [2] \\
\hline $\begin{array}{l}: .13676 \mathrm{G}>\mathrm{A} \\
\mathrm{J} . \mathrm{R} 4558 \mathrm{Q}\end{array}$ & $\begin{array}{l}\text { c. } 2455 C>T \\
\text { p.R819X }\end{array}$ & R4558Q & $50 \%$ & Reduced & Cores & $\begin{array}{l}\text { S100A1 (4426- } \\
\text { 4622) }\end{array}$ & [122] \\
\hline $\begin{array}{l}. .14126 \mathrm{C}>\mathrm{T} \\
0 . \mathrm{T} 4709 \mathrm{M}\end{array}$ & Monoallelic & T4709M & $50 \%$ & Reduced & Cores & & [2] \\
\hline $\begin{array}{l}.14126 \mathrm{C}>\mathrm{T} \\
\text { 0.T4709M }\end{array}$ & $\begin{array}{l}\text { c.12541G >A } \\
\text { p.D4181K }\end{array}$ & $\begin{array}{l}\text { T4709M \& } \\
\text { D4181K }\end{array}$ & $100 \%$ & - & Cores & $\mathrm{Ca}^{2+}(4245-4378)$ & [125] \\
\hline $\begin{array}{l}.14524 C>A \\
\text { o.V4842M }\end{array}$ & $\begin{array}{l}\text { c. } 10348 \mathrm{C}>\mathrm{T} \\
\text { intronic splice } \\
\text { variant } \\
\end{array}$ & V4842M & $50 \%$ & - & CNM & $\begin{array}{l}\text { Interdomain } \\
(4821-4842)\end{array}$ & [4] \\
\hline $\begin{array}{l}.10348-6 C>G \\
\text { o.His3449ins } \\
\text { 33aafsX54 } \\
. .14524 G>A \\
\text { o.V4842M }\end{array}$ & $\begin{array}{l}\text { c.7324-1G>T } \\
\text { p.Leu2442_ } \\
\text { Ala2454>ProfsX86 }\end{array}$ & V4842M & $50 \%$ & Reduced & Cores (severe) & $\begin{array}{l}\text { Interdomain } \\
\text { zipper } \\
(4821-4842)\end{array}$ & [122] \\
\hline $\begin{array}{l}. .14545 G>A \\
0 . V 4849 \mid\end{array}$ & \begin{tabular}{|l|} 
c. 1742.1743 insTCA \\
p. $\mathrm{H} 581 \mathrm{G} \ln \mathrm{X}$
\end{tabular} & V4849I & $50 \%$ & Not known & Cores (severe) & & [122] \\
\hline $\begin{array}{l}. .14731 \mathrm{G}>A \\
. \mathrm{D} 4911 \mathrm{~K}\end{array}$ & \begin{tabular}{|l|} 
c.7006C $>\mathrm{T}$ \\
p.N2336C \\
\end{tabular} & \begin{tabular}{|l|} 
D4911K \& \\
N2336C \\
\end{tabular} & $100 \%$ & - & & $\begin{array}{l}\text { Triadin (4861- } \\
4918 \text { ) }\end{array}$ & [125] \\
\hline $\begin{array}{l}. .10343 \mathrm{C}>\mathrm{T} \\
\text { ग.S3448F}\end{array}$ & $\begin{array}{l}\text { c.14365-2A }>\mathrm{T} \\
\text { acceptor splice site }\end{array}$ & \begin{tabular}{|l|} 
p.S3448F \& \\
p.S4789_ \\
K4822del \\
\end{tabular} & $50-100 \%$ & - & Cores & $\begin{array}{l}\text { DHPR Cav }_{1.1} \\
(2642-3770)\end{array}$ & [2] \\
\hline $\begin{array}{l}.8692+131 G>A \\
\text { o.Gly } 2898 \text { Gly } \\
\text { sX36+ }\end{array}$ & $\begin{array}{l}\text { c.8692+131G>A } \\
\text { p.Gly2898GlyfsX36 } \\
+\end{array}$ & $\begin{array}{l}20 \% \text { wild } \\
\text { type } \\
\text { transcript } \\
\end{array}$ & & Reduced & & & [125] \\
\hline
\end{tabular}


1 Abbreviations: c., coding sequence; p., protein sequence; $X$, stop codon; $C N M$, centronuclear

2 myopathy; CFTD, congenital fiber type disproportion; $\mathrm{MmD}$, multi-minicore disease; $\mathrm{MHS}$,

3 malignant hyperthermia susceptibility; rhabdo, rhabdomyolysis; FSD, fiber-size disproportion;

4 DHPR, dihydropyridine receptor; CaM, calmodulin. -, data not available.

$5 *$ compared with normal RyR1 expression levels. Monoallelic refers to when only one RYR1 allele

6 was seen on analysis of cDNA in patient muscle. A second 'null' mutation likely exists in these

7 patients but has not been identified. 